\title{
GUNSLINGERS ON THE HIGH SEAS: A CALL FOR REGULATION
}

\author{
YVONNE M. DUTTON*
}

\section{TABLE OF CONTENTS}

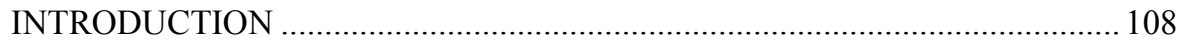

I. THE PROBLEM OF MODERN MARITIME PIRACY ............................... 112

A. The Nature of Modern Maritime Piracy .................................................. 112

B. The International Community's Coordinated Naval Efforts to

Combat the Threat of Modern Maritime Piracy .................................. 115

C. The Continuing Threat of Maritime Pirate Attacks despite

Coordinated Naval Patrols

II. USING PRIVATE ARMED GUARDS IN COUNTER-PIRACY

OPERATIONS

A. Ship Owners Pay for Private Armed Guards to Fill the Security

Gap in Naval Counter-Piracy Operations.

B. The Risks and Difficulties Associated with Allowing Ship Owners

to Hire Private Armed Guards

C. The Maritime Industry's Evolving Stance on Private Armed

Guards

IV. PRIVATE ARMED GUARDS ON SHIPS: A COMPARISON OF

SOME FLAG STATE APPROACHES

A. Overview: States Included in the Study and Their General

Approaches to Regulating the Use of Private Armed Guards

B. Laws and Guidance to Regulate the PMSC Industry or Vet Guards .... 138

C. Laws and Guidance on the Use of Force.

D. Laws and Guidance on Weapons Carriage.

V. A CALL FOR MORE COORDINATED REGULATION

A. The Regulation and Monitoring of the PMSC Industry Generally....... 150

B. Use of Force

C. Weapons Carriage

Copyright (C) 2013 by Yvonne M. Dutton.

* Associate Professor, Indiana University Robert H. McKinney School of Law. A version of this article has also been published in THE HAMBURG LECTURES ON MARITIME AFFAIRS 2013 (Jürgen Basedow et al. eds., 2013). 


\section{INTRODUCTION}

Until very recently, commercial vessels travelling through waters that pose the greatest risk of pirate attacks typically relied on the world's navies to protect them. Indeed, the world community has spent more than one billion dollars in each of the last several years to support naval fleets that patrol pirate-infested waters, with the goal of repressing piracy. ${ }^{1}$ The vastness of the area in which pirates now operate, however, has meant that those navies simply cannot keep every ship safe. ${ }^{2}$ Despite the presence of the world's navies, pirates staged 439 violent attacks and held 802 crew members hostage in 2011 alone. ${ }^{3}$ The rewards they reaped for doing so are great - the average ransom paid to pirates in 2011 was $\$ 4.97$ million. ${ }^{4}$

Calls to fill this apparent security gap left open by the limitations of the naval fleets has resulted in a relatively new phenomenon: since about mid-2011, flag states ${ }^{5}$ have increasingly authorized their ship owners to hire private armed guards to protect them against acts of maritime piracy. Estimates indicate that in 2011 the percentage of ships employing armed guards rose from approximately $10 \%$ to $50 \%{ }^{6}$ Ship owners hire guards from the 200 to 300 private maritime security companies (PMSCs) ${ }^{7}$ that

1. Jon Bellish et al., The Economic Cost of Somali Piracy 13-15 (Oceans Beyond Piracy, Working Paper, 2013), available at http://oceansbeyondpiracy.org/sites/default/files/ecop2012final_2 .pdf; Anna Bowden \& Shikha Basnet, The Economic Cost of Somali Piracy 2011, at 27 (One Earth Future Found., Working Paper, 2012), available at http:/oceansbeyondpiracy.org/sites/default/files/ economic_cost_of_piracy_2011.pdf; David Gauvey Herbert, Piracy is Down, and Moving Farther Out, Burn After Reading, NAT'L J. (Apr. 21, 2010, 4:49 PM), https://web.archive.org/web/20101205065950/ http:/burnafterreading.nationaljournal.com/2010/04/piracy-is-down-and-why-thats-b.php.

2. See David C. Ake, Defense Official: More Private Security Needed Aboard Ships to Combat Piracy, NAT'L DEF. (June 16, 2011, 4:10 PM), http://www.nationaldefensemagazine.org/blog/Lists/ Posts/Post.aspx?ID=447 (stating that there are not enough navies in the world to provide protection to every ship travelling through the 2.9 million nautical miles of ocean in which pirates operate); see also Bowden \& Basnet, supra note 1 , at 8 (stating that in the past four years, pirates have expanded their operations from the Gulf of Aden well into the larger Indian Ocean).

3. See Int'l Mar. Bureau, Int'L Chamber of Commerce, Piracy AND Armed Robbery AgAinst ShIPS, REPORT FOR THE PERIOD 1 JANUARY-31 DeCEMBER 2011, at 5-6, 11 (2011) [hereinafter ICC-IMB 2011 REPORT].

4. Bowden \& Basnet, supra note 1 , at 11 .

5. Ships fly the flag of a single state and are subject to the jurisdiction of that state on the high seas. They must follow its licensing rules and regulations. See generally United Nations Convention on the Law of the Sea arts. 91-92, Dec. 10, 1982, 1833 U.N.T.S. 397 [hereinafter UNCLOS].

6. Nicolas Florquin, Graduate Inst. of Int'1 \& Dev. Studies, Escalation at Sea: Somali Privacy and Private Security Companies, in SMall Arms Survey 2012: Moving TARgets 191, 206 (2012) [hereinafter SMALL ARMS SURVEY 2012]; Bowden \& Basnet, supra note 1, at 17.

7. I use the label "private maritime security companies" to describe these firms because it is the label adopted by the International Maritime Organization (IMO). E.g., Int'l Maritime Org. [IMO], 
have rushed in to capitalize on the apparent security gap. ${ }^{8}$ There is no official central registry identifying the security personnel employed on commercial ships. In 2011, however, at least 2,700 private armed guards may have been operating in the Indian Ocean. ${ }^{9}$

The obvious benefit of permitting private armed guards to aid the world's navies in the fight against piracy is that they may save a ship and crew from attack. An oft-cited anecdote suggests that no ship carrying armed guards has been successfully pirated. ${ }^{10}$ On the other hand, permitting private citizens to engage in activities that have thus far been reserved for state military personnel poses risks. Military personnel-like those participating in the United Nations-sanctioned anti-piracy missionsare trained to operate on the high seas and to follow a chain of command. They are also subject to military discipline or other state laws should they commit abuses. By contrast, private armed guards may not be trained in maritime operations or may not understand or be prepared to abide by the various state laws that govern the use or transport of weapons as they travel from one location to the next. ${ }^{11}$ Further, no coordinated set of guidelines currently regulates the use of private armed guards on ships, and states, for the most part, are not interested in vetting potential guards or setting accreditation standards for guards that protect ships while travelling

Interim Guidance to Private Maritime Security Companies Providing Privately Contracted Armed Security Personnel on board Ships in the High Risk Area, IMO Doc. MSC.1/Circ. 1443 (May 25, 2012) [hereinafter Circ. 1443]. The IMO is the United Nations' specialized agency responsible for, among other things, improving maritime safety. Many other, but synonymous, labels exist to describe the firms that provide armed guards to escort ships travelling through areas posing a high risk of pirate attacks. For example, some commentators use the label "private armed security guards." See, e.g.,

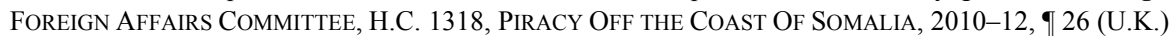
[hereinafter FOREIGN AFFAIRS COMMITTEE 2012 REPORT]. Others use the label "private military security companies." See, e.g., James Brown, PirATES AND PrivateErs: MANAGing THE Indian OCEAN's PRIVATE SECURITY BOOM (2012), available at http://www.lowyinstitute.org/publications/ pirates-and-privateers-managing-indian-oceans-private-security-boom.

8. Sandra I. Erwin, Security Firms Divided Over How to Succeed in the Anti-Piracy Business, NAT'L DEF., Aug. 2012, at 20, available at http://www.nationaldefensemagazine.org/archive/2012/ August/Pages/SecurityFirmsDividedOverHowtoSucceedintheAnti-PiracyBusiness.aspx.

9. BROWN, supra note 7, at 6 .

10. Small ARMS SuRVey 2012, supra note 6, at 208 (noting that this claim may be accurate but cannot be verified).

11. See, e.g., IMO, Interim Guidance to Shipowners, Ship Operators, and Shipmasters on the Use of Privately Contracted Armed Security Personnel on board Ships in the High Risk Area, Annex 91 , IMO Doc. MSC.1/Circ. 1405 (May 23, 2011) [hereinafter Circ. 1405] (noting the issue of identifying reliable private armed security); $i d$. Annex 3.3 (noting the issue of command authority); $i d$. Annex $\emptyset$ 3.4 (noting the issues concerning weapons carriage); id. Annex 93.5 (discussing the need for clear rules on the use of force between the ship owner, PMSC, and master); IMO, Interim Recommendations for Flag States Regarding the Use of Privately Contracted Armed Security Personnel on board Ships in the High Risk Area, Annex 9 3, IMO Doc. MSC.1/Circ. 1406 (May 23, 2011) [hereinafter Circ. 1406] (noting concerns about the possible escalation of violence). 
through pirate-infested waters. ${ }^{12}$ Although private guards may keep ships safe from attack, there are no assurances that they will do so in a way that does not escalate violence, involve unlawful use of force, endanger innocent seafarers, or cause international incidents.

States should not be permitted to include private citizens in the fight against piracy without first ensuring that they will abide by governing laws. Additionally, if the private guards fail to abide by the governing laws, the states must hold them accountable. Currently, only some states provide any guidance regarding the use of armed guards, and even that guidance could be more detailed. ${ }^{13}$ This Article argues that states need to do more. At the very least, it urges states to agree on vetting and monitoring procedures to make certain that any guards who are hired by ship owners are well trained and prepared to safely transport, store, and use weapons. States are responsible for the fight against piracy, and if they want to include private contractors in that fight, they should act responsibly by regulating and monitoring the guards' conduct. Otherwise, in a world in which each state is operating under a different set of rules, or no rules at all, the likely outcome is chaotic and violent seas-and perhaps the next "Blackwater moment."14

In fact, those "Blackwater moments" may already be occurring, as reports indicate that "some overzealous or untrained guards are shooting indiscriminately, killing pirates and sometimes innocent fishermen before verifying the threat." 15 A March 2011 encounter between private armed guards aboard the bulk cargo vessel Avocet and alleged pirates in the Gulf of Aden illustrates this point. Footage apparently leaked without authorization shows PMSC personnel firing more than one hundred shots at an approaching skiff after their team leader ordered them to fire "warning shots." 16 The firing continues even after the skiff, whose driver had been

12. See discussion infra Part IV.A.

13. See discussion infra Part III (discussing the increase in the number of states authorizing the use of armed security personnel and providing details about some state laws and guidance in that regard).

14. See Michelle Wiese Bockmann \& Alan Katz, Shooting to Kill Pirates Risks Blackwater Moment, BLOOMBERG (May 8, 2012, 7:31 PM ET), http://www.bloomberg.com/news/2012-0508/shooting-to-kill-pirates-risks-blackwater-moment.html (referencing the 2007 incident during which security guards employed by Blackwater Worldwide allegedly shot and killed civilians in Baghdad); see also Katharine Houreld, Private Guards Kill Somali Pirate for First Time, SAN DIEGo UNION-TRIB. (Mar. 24, 2010, 1:57 AM), http:/www.utsandiego.com/news/2010/Mar/24/private-guards-kill-somalipirate-for-first-time/?\#article-copy (referencing concerns that jittery private guards could accidentally open fire on ordinary Somali fishermen).

15. Bockmann \& Katz, supra note 14 .

16. See id. (quoting a representative of Eagle Bulk Shipping, which owns the Avocet, asserting that the footage should never have become public). 
either injured or killed in the exchange, crashes into the Avocet. ${ }^{17}$ The PMSC has defended the actions of its personnel as justified, stating that the guards feared for their lives and were acting in self-defense. ${ }^{18}$ A maritime industry expert concluded, however, that the video demonstrates that the guards used excessive force to respond to the alleged attack. ${ }^{19}$ He suggests that the guards never fired actual warning shots and that the rapid and sustained rate of gunfire was not an acceptable response to the threat. ${ }^{20}$ The maritime security industry is concerned that similar incidents are occurring but are not being reported or investigated for fear of liability or other consequences. $^{21}$

One can argue that only states and their navies should be responsible for protecting the world's ships and crews against pirate attacks. Yet circumstances dictate that not all roles in the fight against piracy will be played only by state navies and United Nations-sanctioned military operations: the responsibilities of private armed guards will be ever more accepted. This Article recognizes the need to adapt to this new reality of increasing privatization of tasks that were once assigned to states and their militaries. $^{22}$ At the same time, it urges states as a whole to accept responsibility for ensuring that the private guards who are authorized to use weapons to fight pirates in international waters only operate under a clear and coordinated set of laws and guidelines.

This Article continues in Part I with a brief discussion of modern maritime piracy and the international community's efforts to combat it using naval patrols. Part II provides background on private armed guards, the services they provide, the risks associated with permitting ship owners

17. Id.

18. Id.

19. Id. (citing Daren Knight, a maritime security consultant, who argues that the guards used excessive force, which violates international law on the use of force).

20. Id.

21. See, e.g., id.; Michelle Wiese Bockmann, Ships with Armed Guards Seen Not Reporting Somali Pirate Strikes, BloOMBERG (Oct. 23, 2012, 6:37 AM ET), http://www.bloomberg.com/news/ 2012-10-23/ships-with-armed-guards-seen-not-reporting-somali-pirate-strikes.html.

22. Although employing private armed guards in the fight against piracy is a new phenomenon, states have been using private individuals and firms to supply a wide range of military and security services since the 1950s, a trend that increased dramatically in the early 1990s. Jackson Nyamuya Maogoto \& Benedict Sheehy, Private Military Companies \& International Law: Building New Ladders of Legal Accountability \& Responsibility, 11 CARDOZO J. CONFLICT RESOL. 99, 105 (2009). Probably most familiar to readers is the role private military employees played in the recent wars in Afghanistan and Iraq. Indeed, records indicate that as of March 2010, at least 60 different privatized military firms were providing personnel from at least 30 different countries to support operations in Iraq. Huma $\mathrm{T}$. Yasin, Playing Catch-Up: Proposing The Creation Of Status-Based Regulations To Bring Private Military Contractor Firms Within The Purview Of International And Domestic Law, 25 EMORY INT'L L. REV. 411, 415 (2011). 
to hire armed security personnel to provide individualized protection against pirate attacks, and the maritime industry's evolving stance on the issue. Part III explores and compares some of the different approaches states have used to address and regulate the use of armed guards in the fight against piracy. Part IV addresses deficiencies in the current approaches and suggests standards or practices to mitigate the risks associated with private guards wielding weapons on the world's oceans, on which all states should agree.

\section{THE PROBLEM OF MODERN MARITIME PIRACY}

\section{A. The Nature of Modern Maritime Piracy}

Presently, maritime piracy plays a prominent role on the global stage. For the past several years, reports of violent attacks on ships and hefty ransom payments to secure the safe release of captains and crews have become a regular feature of the world's daily news. ${ }^{23}$ Although not all of those attacks are linked to Somalia, the emergence of Somali piracy on a grand scale beginning in the mid-2000's helps to illustrate the increased global threat posed by maritime piracy. $^{24}$ The International Maritime Bureau (IMB) Piracy Reporting Centre reported 1,850 worldwide pirate attacks between January 2007 and December 2011. ${ }^{25}$ Attacks during 2009,

23. See, e.g., Hijacked Vietnamese Cargo Ship Expected to Be Ransomed for $\$ 5$ Mln, TALK VIETNAM (Oct. 25, 2012), http://talkvietnam.com/2012/10/hijacked-vietnamese-cargo-ship-expected-tobe-ransomed-for-5-mln/ (reporting on the January 2012 capture of a Vietnamese cargo ship 520 miles off the coast of Oman); Somali Pirates Capture Supertanker, \$150M of Oil, USA TODAY (Feb. 10, 2011, 1:41 AM), http://usatoday30.usatoday.com/news/world/2011-02-09-pirates-hijack-supertanker N.htm (reporting that in February 2011 Somali pirates captured the Greek supertanker MV Irene SL and its two million barrels of crude oil while the tanker was travelling 200 miles off the coast of Oman); Somali Pirates Release Greek-Owned VLCC, Hijack German Cargo Ship the Next Day, MAR. EXECUTIVE (Apr. 11, 2011), http://www.maritime-executive.com/article/somali-pirates-release-greekowned-vlcc-mv-irene-sl (reporting that in April 2011 Somali pirates attacked the MV Susan K, a German cargo ship, while it was travelling 35 miles off the coast of Oman); Somali Pirates Hijack Russian China-bound Oil Tanker, BBC News, BBC.COM (May 5, 2010, 16:24 GMT), http://news.bbc.co.uk/2/hi/8661816.stm (reporting that in May 2010 pirates attacked a 96,000 ton oil tanker 560 miles off the Somali coast); Xan Rice \& Lee Glendinning, Pirates Anchor Hijacked Supertanker off Somali Coast, GUARDIAN (Nov. 18, 2008, 13:15 EST), http://www.guardian.co.uk/ world/2008/nov/18/somalia-oil (reporting on the 2008 capture of a Saudi supertanker 450 miles off the coast of Kenya).

24. See, e.g., Special Advisor on Legal Issues Related to Piracy off the Coast of Somalia, Report of the Special Advisor to the Secretary-General on Legal Issues Related to Piracy off the Coast of Somalia, transmitted by letter dated 24 January 2011 from the Secretary-General to the President of the Security Council, If 12, U.N. Doc. S/2011/30 (Jan. 24, 2011) (by Jack Lang) [hereinafter Lang Report] (referencing the increase in Somali piracy in 2005 after a tsunami led to further instability in the country).

25. ICC-IMB 2011 REPORT, supra note 3, at 5-6 (providing graphical break-downs of piracy 
2010, and 2011 numbered more than 400 each year-an amount that exceeds the total reported attacks in 2007 by more than 50 percent. $^{26}$ The IMB reports fewer successful attacks in 2012 than in the several prior years, ${ }^{27}$ but it is not yet time for celebration. Between January and September 2012, 585 seafarers were taken hostage-as compared to 172 during the same time period in $2007 .^{28}$ Six seafarers were killed by pirates during 2012. ${ }^{29}$ These numbers are startling, even if they are lower than in some prior years. As a recent United Nations Secretary-General Report warns: "Although there are signs of progress, they can easily be reversed." 30

Although the number of attacks is down, piracy still poses a significant threat to the safe passage of vessels travelling through shared sea-lanes. Pirates are sophisticated criminals who use violence to mount their attacks. ${ }^{31}$ The IMB reports that guns were used in 113 of the attacks that occurred during $2012^{32}$ and that most attacks by Somali pirates now involve the use of weapons. ${ }^{33}$ Somali pirates are able to operate hundreds of nautical miles out to sea where they use larger fishing vessels - known

attacks between January 2007 and December 2011). In its annual report, the IMB includes acts of piracy and acts of armed robbery against ships, as well as attempts of the same. The IMB's definition of piracy includes illegal acts of violence against a ship travelling on the high seas or any act of inciting the same. $I d$. at 3. Its definition of armed robbery against ships includes acts of violence - or any act inciting an act of violence - against a ship located "within a State's internal waters, archipelagic waters and territorial sea." Id.

26. Id. at 5-6 (showing 263 actual and attempted attacks in 2007 as compared to 439 in 2011).

27. See Int'l mar. Bureau, Int'L Chamber of Commerce, Piracy and Armed Robbery Against ShIPS, RePORT FOR THE PERIOD 1 JANUARY-31 DeCEMBER 2012, at 5-6 (2012) [hereinafter ICC-IMB 2012 REPORT] (showing a total of 297 actual and attempted attacks for the year 2012). As is the case with prior years, the actual number of attacks may be greater than the number reported since the general belief is that shipping companies may underreport to avoid insurance premium increases. Eugene Kontorovich \& Steven Art, An Empirical Examination of Universal Jurisdiction for Piracy, 104 AM. J. INT'L L. 436, 440-41 (2010). In fact, the results of a study by the British House of Commons Transport Committee indicated that potentially $25-50 \%$ of maritime piracy crimes are unreported. James Kraska \& Brian Wilson, The Pirates of the Gulf of Aden: The Coalition Is the Strategy, 45 STAN. J. INT'L L. 243, 257 (2009).

28. ICC-IMB 2012 REPORT, supra note 27, at 11.

29. Id.

30. U.N. Secretary-General, Report of the Secretary-General Pursuant to Security Council Resolution 2020 (2011), ๆ 74, U.N. Doc. S/2012/783 (Oct. 22, 2012) [hereinafter S/2012/783 Report].

31. See, e.g., Lang Report, supra note 24, ๆ 13 (stating that piracy has "become an organized, lucrative and attractive criminal activity undertaken for heinous ends"); LAUREN PLOCH ET. AL, CONG. ReSEARCh Serv., R40528, Piracy Off the Horn of Africa 9 (Apr. 27, 2011) [hereinafter Ploch 2011] (noting that "some Somali pirate groups have developed sophisticated operational capabilities and have acquired weaponry, equipment, and funds that make them on par with or more effective than the local forces arrayed against them").

32. ICC-IMB 2012 REPORT, supra note 27 , at 10.

33. Id. at 20 . 
as "mother ships" (often acquired by acts of piracy) - from which they mount their attacks. ${ }^{34}$ From these mother ships, the pirates use small maneuverable skiffs powered with large outboard motors. ${ }^{35}$ With the help of AK-47 rifles and rocket propelled grenade launchers, today's pirates have successfully attacked some of the world's largest supertankers. ${ }^{36}$

Pirate attacks do not just harm individuals travelling on the ships that are captured. Piracy threatens the world economy and global trade, since $90 \%$ of the world's traded goods move by sea. ${ }^{37}$ Somali piracy is a particular danger to the $40 \%$ of world sea trade that passes through the Indian Ocean, the Gulf of Aden, and the Arabian Sea. ${ }^{38}$ While Somali pirates at one time operated within a concentrated geographical area in the waters off the coast of Somalia and the Gulf of Aden, they have more recently expanded their reach farther into the Indian Ocean. ${ }^{39}$ Additionally, pirate attacks on ships carrying oil threaten world energy supplies. ${ }^{40}$ Piracy also jeopardizes the delivery of humanitarian assistance to the Horn of Africa. ${ }^{41}$

Moreover, the increasingly hefty ransoms paid to guarantee the release of innocent seafarers provide an incentive for pirates to continue their illegal and violent activities. In 2011, pirates received an estimated $\$ 170$ million in ransom payments, a huge increase from the total of $\$ 110$ million they received in $2010 .{ }^{42}$ In fact, the ransoms paid to pirates "have increased sevenfold over the last five years," with average ransoms increasing from about $\$ 600,000$ in 2007 to about $\$ 5$ million in $2011^{43}$

34. Lauren Ploch et. Al, Cong. Research Serv., R40528, Piracy Off the Horn of Africa 11 (Apr. 19, 2010) [hereinafter PLOCH 2010].

35. Id.

36. See, e.g., Somali Pirates Capture Supertanker, \$150M of Oil, supra note 23 (reporting the capture of the Greek supertanker MV Irene SL); Somali Pirates Release Greek-Owned VLCC, Hijack German Cargo Ship the Next Day, supra note 23 (reporting the capture of the MV Susan K, a German cargo ship).

37. Foreign AfFAirs COMMITTEe 2012 RePORT, supra note $7, \mathbb{q} 14$.

38. Id.

39. Bowden \& Basnet, supra note 1 , at 8

40. See, e.g., John Stewart, Somali Pirates: Steep Rise in Attacks, News-InSURANCES (Mar. 28, 2011), http://www.newsinsurances.co.uk/somali-pirates-steep-rise-in-attacks/0169475872 (reporting pirates' seizure of the Irene $S L$, a tanker carrying two million barrels of Kuwaiti oil to the United States).

41. For example, the World Food Program transports about ninety-five percent of its supplies by sea. U.N. Secretary-General, Report of the Secretary-General Pursuant to Security Council Resolution 1846 (2008), ๆ 35, U.N. Doc. S/2009/146 (Mar. 16, 2009).

42. $S / 2012 / 783$ Report, supra note $30, \uparrow 6$.

43. FOREIGN AFFAIRS COMMITTEe 2012 RePORT, supra note 7, ๆ 111. Some ransoms recently paid to Somali pirates have been significantly higher. In fact, in February 2011, pirates received a $\$ 13.5$ million ransom payment to release the $M V$ Irene, a supertanker carrying 2 million barrels of 
B. The International Community's Coordinated Naval Efforts to Combat the Threat of Modern Maritime Piracy

Although maritime piracy remains a significant threat, the international community has engaged in some coordinated efforts to combat it. In 2007, some countries began providing naval escorts to World Food Program ships delivering humanitarian aid. ${ }^{44}$ Since then, those naval escorts have accompanied about 150 vessels carrying essential humanitarian assistance. ${ }^{45}$ Beginning in late 2008, countries also began contributing naval resources to conduct counter-piracy operations. Multinational naval forces (Combined Task Forces 150, 151, and 152), involving twenty-seven different states, operate around the Gulf of Aden, the Arabian Sea, and the Indian Ocean with the stated aim of deterring, disrupting, and suppressing acts of piracy. ${ }^{46}$ These forces have been joined by others, such as the European Union's combined naval force (Operation Atalanta). ${ }^{47}$ The Council of the European Union has authorized Atalanta to operate until December 2014 and has allowed it to expand the reach of its activities to the coast and internal waters of Somalia. ${ }^{48}$ NATO has also sent ships on anti-piracy missions to the Horn of Africa. ${ }^{49}$ Other states, including Russia, China, India, South Korea, Japan, Malaysia, and Singapore, have complemented these multi-national operations by sending their own ships to patrol in the waters off the Somali coast. ${ }^{50}$ In total, between ten and sixteen naval ships conduct anti-piracy missions in the Gulf of Aden and Indian Ocean on any given day. ${ }^{51}$

Since 2008, the United Nations Security Council has backed these

Kuwaiti oil destined for the United States and estimated to be worth \$200 million. Bowden \& Basnet, supra note 1 , at 11 .

44. Defence Committee, European Security and Defence Assembly/Assembly of Western European Union [ESDA], Report: The Role of the European Union in Combating Piracy, \ 46, ESDA Doc. No. A/2037 (June 4, 2009) (Kurt Bodewig, Aristotelis Pavlidis \& Tarmo Kõuts) [hereinafter Report: The Role of the European Union in Combating Piracy]; ROGER MidDLETON, PIRACY IN Somalia: ThreAtening Global Trade, FeEding Local WARS 7 (2008), available at http://www.chathamhouse.org/files/12203_1008piracysomalia.pdf. In March 2010, China offered to deploy naval forces to assist European Union forces that were escorting World Food Program ships. PLOCH 2010, supra note 34, at 16.

45. S/2012/783 Report, supra note 30, \ 34.

46. FOREIGN AFFAIRS COMMITTEE 2012 REPORT, supra note 7, $₫ 44$.

47. Id.; see also Peter Chalk, Piracy Off the Horn of Africa: Scope, Dimensions, Causes and Responses, 16 BROWN J. WORLD AFF. 89, 98 (2010) (describing NATO's cooperation with Operation Atalanta).

48. S/2012/783 Report, supra note 30, ๆ 34.

49. Id. ๆ 35; Chalk, supra note 47, at 98; PLOCH 2010, supra note 34, at 24.

50. FOREIGN AFFAIRS COMMITTEE 2012 REPORT, supra note 7, $₫ 44$.

51. Bowden \& Basnet, supra note 1 , at 25. 
coordinated naval efforts to counter piracy with a number of resolutions authorizing military action against Somali pirates at sea and on Somali territory. Under Resolution 1816, the Security Council authorized coalition navies cooperating with the Transitional Federal Government (TFG) of Somalia to enter Somalia's territorial waters and use "all necessary means to repress acts of piracy and armed robbery" for an initial period of six months. ${ }^{52}$ That authorization was extended for one year under Resolution 1846. ${ }^{53}$ The Security Council authorized even broader military action to combat piracy under Resolution 1851, allowing states to use land-based operations in Somalia to fight piracy. ${ }^{54}$ Under Resolution 1897, it extended the scope of allowable anti-piracy operations in Somalia's territorial waters for another twelve months. ${ }^{55}$ Recent Security Council resolutions urge states to continue contributing to the naval forces that patrol the pirateinfested waters off the coast of Somalia. ${ }^{56}$

All of these coordinated naval efforts have likely contributed to the present reduction in the total number of reported and attempted attacks. ${ }^{57}$ In fact, naval forces apparently "thwarted 126 attacks in 2008, 176 in 2009 and 127 in 2010."58 Furthermore, no World Food Program ship has been hijacked since the ships began receiving escorts from the world's navies. ${ }^{59}$ Similarly, ships travelling through the Gulf of Aden corridor have not been successfully attacked since naval forces began organizing commercial shipping vessels into transit groups. ${ }^{60}$ This process allows the navies to closely watch a designated number of ships to which they can promptly respond should they receive distress calls. ${ }^{61}$ The naval forces have also successfully captured pirates who have attacked or attempted to attack ships at sea. Reports indicate that between January and August 2009 alone, the world's naval forces "encountered" more than 500 pirates, 10 of whom were killed, 282 of whom were disarmed and released, and 235 of whom were transferred for prosecution. ${ }^{62}$

52. S.C. Res. 1816, ๆ 7, U.N. Doc. S/RES/1816 (June 2, 2008).

53. S.C. Res. 1846, 10, U.N. Doc. S/RES/1846 (Dec. 2, 2008).

54. S.C. Res. 1851, $\llbracket$ 6, U.N. Doc. S/RES/1851 (Dec. 16, 2008).

55. S.C. Res. 1897, ๆ 7, U.N. Doc. S/RES/1897 (Nov. 30, 2009).

56. E.g., S.C. Res. 1950, ๆ 4, U.N. Doc. S/RES/1950 (Nov. 23, 2010); S.C. Res. 2020, ๆ 7, U.N. Doc. S/RES/2020 (Nov. 22, 2011).

57. See S/2012/783 Report, supra note 30 , 94 (noting that the actions by the naval forces have aided in reducing the number of successful pirate attacks).

58. Lang Report, supra note 24, ๆ 39.

59. FOREIGN AFFAIRS COMMITTEE 2012 REPORT, supra note 7, \ 49.

60. Id. ๆ 49.

61. Id. $₫ 50$.

62. PLOCH 2010, supra note 34, at 22. 


\section{The Continuing Threat of Maritime Pirate Attacks despite Coordinated Naval Patrols}

Despite the fact that the international community is spending more than $\$ 1$ billion annually to support the various naval patrols, ${ }^{63}$ the threat of maritime piracy persists. The world's navies have thwarted attacks, and the number of successful attacks is down in 2012. The threat posed by piracy, however, remains real to individual seafarers and the international community. Further, before 2012, the number of pirate attacks was growing in absolute terms, even as navies patrolled in an effort to help secure the safe passage of ships. ${ }^{64}$

Some partially attribute the continued prevalence of piracy on the navies' general "catch and release" policies. ${ }^{65}$ According to some reports, about $90 \%$ of pirates are released after capture, rather than being transferred to stand trial for their actions. ${ }^{66}$ Recent figures indicate that between 2006 and September 2012, about 1,186 suspected pirates have been prosecuted or await prosecution in twenty-one states. ${ }^{67}$ Yet this is only a small fraction of the number of pirates who have been captured attacking or attempting to attack ships. ${ }^{68}$

Unless states are prepared to prosecute a sufficient number of pirates to send a signal that their criminal acts will not be tolerated, they must stop

63. See Bowden \& Basnet, supra note 1, at 24 (estimating that in 2011, nations spent about \$1 billion deploying the various naval patrols conducting anti-piracy missions in the Gulf of Aden and Indian Ocean).

64. See Lang Report, supra note 24, 939 (stating that the number of pirate attacks was increasing year over year notwithstanding the significant anti-piracy naval missions); FOREIGN AFFAIRS COMMITTEE 2012 REPORT, supra note 7, at 3 (stating that naval operations, among other things, had failed to "contain the growth in the overall number of attacks and the areas in which pirates can operate").

65. U.N. Secretary-General, Report of the Secretary-General on Possible Options To Further the Aim of Prosecuting and Imprisoning Persons Responsible for Acts of Piracy and Armed Robbery at Sea off the Coast of Somalia, Including, in Particular, Options for Creating Special Domestic Chambers Possibly with International Components, a Regional Tribunal or an International Tribunal and Corresponding Imprisonment Arrangements, Taking into Account the Work of the Contact Group on Piracy off the Coast of Somalia, the Existing Practice in Establishing International and Mixed Tribunals, and the Time and Resources Necessary to Achieve and Sustain Substantive Results, 9 9, U.N. Doc. S/2010/394 (July 6, 2010) ("In order to be effective, naval operations apprehending suspects should result in prosecutions. The risk otherwise is that suspects are released at sea, or repatriated, and return to commit further acts of piracy or armed robbery at sea.").

66. Lang Report, supra note 24, ๆథ 42-43.

67. S/2012/783 Report, supra note $30, \uparrow 44$.

68. Lang Report, supra note 24, ๆ $42-43$ (noting that states prosecuted about $1 / 3$ of the pirates captured between 2008 and 2010 but that, by 2011, states were releasing more than $90 \%$ of captured pirates). 
pirates before they are able to mount their attacks. ${ }^{69}$ The anti-piracy naval patrols, however, simply do not have the capacity to secure the safe passage of every transiting ship. ${ }^{70}$ In many cases, pirates are able to board and take hostages within fifteen to thirty minutes of being sighted. ${ }^{71}$ This amount of time is too short for a naval ship to respond unless it is only a few miles away. ${ }^{72}$ Indeed, the world's "[n]aval forces have found it difficult to monitor pirates and to respond swiftly to attacks ....,73 According to the United Kingdom's Major General Howes (Operation Commander of Atalanta), about " 83 [ships] would be needed in order to provide response conditions of half an hour."74 William Wechsler, the United States Deputy Assistant Secretary of Defense for Counternarcotics and Global Threats, offers a more pessimistic view, suggesting that pirates now operate within an area of approximately 2.9 million nautical miles and that all the navies in the world could not possibly protect such a space. ${ }^{75}$

Thus, while naval ships have been successful in thwarting some pirate attacks, at present they do not have the capacity to protect every ship travelling through the Indian Ocean. Moreover, there is reason to believe that states will provide fewer naval resources for counter-piracy efforts in the upcoming years because of budgetary pressures. This state of affairs has caused some stakeholders in the fight against piracy to focus on the role private armed guards might play in protecting ships, cargo, and crews against attacks. $^{76}$ The recent increased reliance on armed guards to assist in the fight against maritime piracy and the risks associated with relying on them is discussed in Part II below.

69. See FOREIGN AFFAIRS COMMITTEE 2012 REPORT, supra note 7, at 40 (noting that simply returning pirates to sea or land may disrupt their activities but will likely have no long-term deterrent effect).

70. See Bowden and Basnet, supra note 1, at 25 (predicting a decrease in EUNAVFOR, NATO, and national contributions to the fight against piracy due to decreased defense expenditures); FOREIGN AFFAIRS COMMITTEE 2012 REPORT, supra note 7, 51 (noting that as naval operations have become more successful at ensuring ships safe passage through the Gulf of Aden corridor, pirates have expanded their activities into the larger Indian Ocean, increasing exponentially the difficulty of securing the high seas).

71. PLOCH 2011, supra note 31, at 10.

72. Id. at 10-11.

73. FOREIGN AFFAIRS COMMITTEE 2012 REPORT, supra note 7, 951.

74. Id.

75. Ake, supra note 2

76. See Foreign AFFAIRs COMMITTEE 2012 REPORT, supra note 7, - 25 (noting that some in the shipping industry have called on states to allow them to pay to have armed military personnel on board their ships when transiting through pirate-infested waters); PLOCH 2011, supra note 31, at 36 (noting that some industry representatives have argued for the ability to hire armed security teams to deter and respond to pirate attacks). 


\section{USING PRIVATE ARMED GUARDS IN COUNTER-PIRACY OPERATIONS}

\section{A. Ship Owners Pay for Private Armed Guards to Fill the Security Gap in Naval Counter-Piracy Operations}

The apparent security gap left open by the limitations of the world's navies caused ship owners to begin calling for more protection of their ships when travelling through pirate-infested waters. ${ }^{77}$ In response, some 200 to 300 PMSCs emerged, the bulk of which were created in $2011 .^{78}$ These companies, which claim to offer some sort of maritime security, now provide armed escorts for $50 \%$ or more of the vessels transiting through areas carrying a high risk of pirate activity. ${ }^{79}$ Most companies providing these maritime security services are British or American and are often founded or staffed by retired military personnel. ${ }^{80}$ The cost of hiring private guards is not cheap: a PMSC's services to secure a safe passage can range from $\$ 15,000$ to $\$ 100,000$, depending on the number and quality of the guards employed, the ship's size and vulnerability, and the length of the trip. $^{81}$ On the other hand, the expense may be warranted. Notably, as of mid-2012, pirates had not successfully hijacked any commercial ship carrying armed guards. ${ }^{82}$ Moreover, some insurance companies offer significant discounts to vessels employing armed security when travelling through areas that pose a high risk of pirate attacks. ${ }^{83}$

77. See infra Part II.C.

78. BROWN, supra note 7, at 2, 4; Erwin, supra note 8.

79. See Laws and Guns: Piracy and Private Security, ECONOMIST, Apr. 14, 2012, at 69, available at http://www.economist.com/node/21552553 (estimating that private armed guards patrol the decks of about $40 \%$ of the large vessels travelling in pirate-infested waters); Piracy: A Threat to Maritime Security and the Global Economy, DIIRAD (Nov. 14, 2012, 16:06), http://www.diirad.com/news-inenglish/4298-piracy-a-threat-to-maritime-security-and-the-global-economy-.html (estimating that about $60 \%$ of commercial carriers now hire private guards for protection).

80. See ForEIGN AFFAIRS COMMITTEE 2012 REPORT, supra note 7, 26 (estimating that $50 \%$ of PMSCs are British-owned or operated); Laws and Guns: Piracy and Private Security, supra note 79, at 69 (stating that most companies are British and started by Special Forces retirees); BROWN, supra note 7, at 5 (stating that most PMSCs are British or American).

81. Christopher Spearin, Private Military and Security Companies v. International Naval Endeavours v. Somali Pirates: A Security Studies Perspective, 10 J. INT'L CRIM. JuST. 823, 828 (2012).

82. Issues Arising from the Use of Armed Guards, INCE \& CO INT'L LLP, http://incelaw.com/misc/ Piracy-issues-arising-from-the-use-of-armed-guards/Piracy-Issues-arising-from-the-use-of-armedguards (last visited September 26, 2013).

83. See Ship Insurers Offers Discount for Armed Guards on Ship, SHIPPING HERALD: THE MAR. PORTAL (Oct. 24, 2011), http://www.shippingherald.com/Admin/ArticleDetail/ArticleDetailsInsurance/ tabid/121/ArticleID/1366/Ship-Insurers-Offers-Discount-for-Armed-Guards-on-Ship.aspx （reporting that some insurance companies offer premium reductions of up to $35 \%$ for ships with armed guards, resulting in savings of thousands of dollars for some high-value ships). 
PMSCs provide armed guards in one of two ways: using ship-borne armed protection teams or armed convoy escort vessels. ${ }^{84}$ Ship-borne armed protection teams typically consist of three to ten guards who have prior naval or military training. ${ }^{85}$ These guards will often "embark with body armour, medical kits, satellite communications, night-vision equipment and weapons." ${ }^{\prime 86}$ There is no standard type of weapon employed by PMSCs, and a decision on which weapons to provide their personnel may vary from firm to firm and also depends on the nature of the voyage. ${ }^{87}$ Thus, armed guards may be equipped with pistols, shotguns, or even machine guns and sniper rifles. ${ }^{88}$ Protection teams will usually embark from ports near the Gulf of Aden and disembark some days later in southern Sri Lanka so that they can provide security in the waters most prone to pirate attacks. ${ }^{89}$

Ship owners and operators must address the difficulty of boarding weapons when seeking to place armed guards on their ships. Ship owners carrying arms must comply with the flag state laws ${ }^{90}$ and the laws of the state where they are incorporated. ${ }^{91}$ They must also comply with the laws of coastal states through which they transit. ${ }^{92}$ Some coastal states permit PMSCs to store their weapons in the state's ports and sign the weapons on and off the ships that they are assigned to protect, allowing for transparency in PMSC arms procurement and transport. ${ }^{93}$ Other states, however, have strict laws forbidding foreign weaponry in their territories, ${ }^{94}$ while some

84. Spearin, supra note 81 , at 827 .

85. Id. at 827-28; BROWN, supra note 7, at 6 .

86. BROWN, supra note 7 , at 7.

87. SMALL ARMS SURVEY 2012, supra note 6, at 207-08.

88. Id. at 208 .

89. BROWN, supra note 7 , at 7 .

90. As noted above, ships fly the flag of a single state, which is ordinarily the state of the ship's owners. In some cases, however, ships fly "flags of convenience," registering in a sovereign state different from the ship's owners. Flags of convenience jurisdictions are "open registry" states and typically allow ship owners to enjoy lower taxes and less stringent regulations than might the ship's home state. What are Flags of Convenience?, INT'L TRANSP. WORKERS' FED'N, http://www.itfglobal.org/flags-convenience/sub-page.cfm (last visited Sept. 16, 2013). "Closed registry states," like the United States, by contrast, impose relatively strict registry and licensing criteria. Michael A. Becker, The Shifting Public Order of the Oceans: Freedom of Navigation and the Interdiction of Ships at Sea, 46 HARV. INT'L L.J. 131, 142 (2005).

91. SMALl ARMS SuRVEY 2012, supra note 6, at 208.

92. Id.

93. Id. at 209 .

94. For example, it is almost impossible for a private security company to obtain permission for its employees to carry weapons in Singapore. Carolin Liss, The Privatisation of Maritime SecurityMaritime Security in Southeast Asia: Between a Rock and a Hard Place? 16 (Asia Research Ctr., Working Paper No. 141, 2007). 
only allow certain types of weapons. ${ }^{95}$ Due to the complex web of legal requirements relating to the carriage and transport of arms, some PMSCs are dumping weapons at sea to avoid violating arms regulations when calling at ports or disembarking at a final destination. ${ }^{96}$ PMSCs also avoid coastal state regulations by stocking "floating armories" on the high seas. This arrangement allows their personnel to embark on the ship without weapons but to obtain the required weapons once outside of territorial waters. $^{98}$

On the other hand, some coastal states have embraced the profit opportunity associated with the recent rise of the PMSC industry and ship owners' interest in securing armed protection when travelling through pirate-infested waters. For example, Djibouti sells annual permits to PMSCs for $\$ 150,000$ (or more) to allow them to operate from its ports with weapons. ${ }^{99}$ Djibouti also has a program whereby PMSCs can pay to rent and embark government-owned weapons-including fully automatic firearms. ${ }^{100}$ Sri Lanka runs a similar program from its port in Galle, allowing PMSCs to rent government-owned weapons - again including fully automatic firearms. ${ }^{101}$ PMSCs wishing to rent the weapons must also agree to embark a retired or off-duty Sri Lankan military officer to monitor the use of weapons on board the ship. ${ }^{102}$ Yemen has taken a different approach, renting out its own military personnel to escort ships travelling through the Gulf of Aden. ${ }^{103}$

Armed convoy escort vessels are another option offered by some PMSCs to their private clients seeking individualized counter-piracy services. ${ }^{104}$ PMSCs offering this service generally rely on small vessels armed with small crews to conduct these escorts. ${ }^{105}$ Some companies, though, have grander plans. For example, reports indicate that one private company, Typhon, will offer the services of three large boats, each fitted with machine guns and manned with 40 guards carrying rifles. ${ }^{106}$ Both the

95. See SMAll ARMS Survey 2012, supra note 6, at 209 (noting that armed guards aboard German-flagged ships cannot carry semi-automatic rifles).

96. Id. at 210.

97. BROWN, supra note 7 , at 5 .

98. Id.

99. SMALL ARMS SURVEY 2012, supra note 6, at 210.

100. Id.

101. Id.

102. Id.

103. Id. at 210-11.

104. Id. at 207.

105. Spearin, supra note 81 , at 828 .

106. Martin Plaut, Private Patrol Boats to Tackle Somali Pirates, BBC News, BBC.COM (May 30, 
smaller and larger escort vessels operate by accompanying the client's ship on its travels and challenging any suspicious boats that attempt to approach so as to deter any potential attacks. ${ }^{107}$ One advantage for ship owners choosing to employ armed convoy escort vessels is that the owners seemingly avoid the difficulties and legal issues associated with carrying weapons on board since the escort vessels operate separately from the client's ship. ${ }^{108}$

In addition to PMSCs, however, some governments hire out their naval or military personnel to provide security for commercial ships travelling through the Indian Ocean. ${ }^{109}$ Known as vessel protection detachments, or VPDs, these privately hired military teams also offer armed protection against pirate attacks. ${ }^{110}$ For example, the Netherlands does not permit its shipping companies to employ PMSCs, citing concerns that allowing private guards would undermine the state's monopoly on the use of force. ${ }^{111}$ Accordingly, in 2011, it began offering VPDs to its ship owners, half of the cost of which is borne by the private shipping company. ${ }^{112}$ Several other states, including France, Spain, Israel, and Italy, have also hired out their military personnel to guard merchant vessels flying the state's flag. ${ }^{113}$

Indeed, the fact that Italy hired out some of its marines to help guard the Italian ship $M V$ Enrica Lexie as it was travelling from Singapore to Egypt in early 2012 became international news. ${ }^{114}$ Two of those Italian marines were arrested by Indian authorities for having shot two Indian

2012, 04:06 ET), http://www.bbc.co.uk/news/world-africa-18209357.

107. BROWN, supra note 7 , at 8 .

108. Id.

109. Id. at 9 .

110. Id.

111. Id. at 9-10.

112. Justin Stares, The Need for Armed Guards Proves Governments have Failed to Tackle Piracy, DEF. MGMT. (Feb. 28, 2012), https://web.archive.org/web/20121114131259/http:/www .defencemanagement.com/feature_story.asp?id=18807. The cost of hiring VPDs, however, so exceeds the cost of hiring private armed guards employed with PMSCs that some Dutch ship owners simply skirt the law and hire private guards from PMSCs. Id.; see also Dutch Shipowner to Flag Out over Ban on Armed Guards, INTERMANAGER (Nov. 15, 2011), http://www.intermanager.org/2011/11/dutchshipowner-to-flag-out-over-ban-on-armed-guards/ (reporting that one Dutch ship owner planned to register his ships in another state because Dutch laws forbid hiring armed guards from PMSCs). In July 2012, the Dutch Minister of Defense announced that the government was reducing the cost to ship owners of hiring these VPDs. Defence Organisation makes Security for Merchant Shipping Cheaper, NETH. MinistRY OF DEF. (July 13, 2012, 17:59), http://www.defensie.nl/english/latest/news/2012/07/ 13/48197582/Defence_organisation_makes_security_for_merchant_shipping_cheaper.

113. FOREIGN AFFAIRS COMMITTEE 2012 REPORT, supra note 7, \ 25.

114. E.g., Indian Police Detain Italian Navy Security Guards, BBC News, BBC.COM (Feb. 19, 2012, 23:38 ET), http://www.bbc.co.uk/news/world-asia-india-17093224. 
fishermen the marines believed to be pirates. ${ }^{115}$ The marines were thereafter detained and arrested on murder charges despite Italy's argument that they enjoyed immunity from foreign prosecution as agents of the Italian state. ${ }^{116}$ Nevertheless, industry witnesses strongly prefer VPDs over hiring guards employed with PMSCs, in part because they believe that state military personnel will be properly trained and responsive to authority. ${ }^{117}$ Some also believe that military personnel can more easily move weapons through ports and that their legal status, which is more defined than that of private contractors, will protect them against foreign prosecutions should their actions cause any injury or death. ${ }^{118}$ Of course, the Enrica Lexie incident should serve as a warning that even military personnel hired out as part of VPDs have no certain status entitling them to immunity from foreign arrest and prosecution.

\section{B. The Risks and Difficulties Associated with Allowing Ship Owners to Hire Private Armed Guards}

Only a few years ago, industry organizations and states were generally opposed to the idea of private armed guards, preferring to allow only naval fleets to provide anti-piracy protection. ${ }^{119}$ A major criticism of the use of armed guards on commercial ships emphasizes the risk of escalating violence. ${ }^{120}$ Piracy has already become more violent over the last several years, and pirates who know that ships are prepared to use lethal weapons to repel attacks may respond more forcefully. ${ }^{121}$ The United Kingdom's Dr. Campbell McCafferty, Head of Counter-Terrorism and UK Operational Policy at the Ministry of Defense, explained that the presence of armed

115. Id.

116. Amrutha Gayathri, Enrica Lexie: Italy Urges India to Release Detained Marines, INT'L BuS. TIMES (Mar. 12, 2012, 6:26 AM), http://www.ibtimes.com/enrica-lexie-italy-urges-india-releasedetained-marines-423740; India Allows Italian Ship Enrica Lexie to Leave, BBC News, BBC.COM (May 2, 2012, 04:56 ET), http://www.bbc.co.uk/news/world-asia-india-17920840; Mike Schuler, Italy and India Stand Off Over MV Enrica Lexie Incident, GCAPTAIN (Feb. 21, 2012), http://gcaptain.com/italyindia-standoff-enrica-lexie/.

117. Foreign AfFAirs COMMITTEE 2012 REPORT 2012, supra note 7, ๆ 25.

118. See, e.g., Piracy Against U.S. Flag Vessels: Lessons Learned: Hearing before the Subcomm. on Coast Guard \& Mar. Transp. Of the H. Comm. on Transp. \& Infrastructure, 111th Cong. 2 (2009) [hereinafter Volkle Testimony] (statement of Arthur J. Volkle, Jr., Vice President of American Cargo Transport, Inc.), available at http://www.marad.dot.gov/documents/Testimony-Arthur_Volkle,JrAmerican_Cargo_Transport.pdf ("Military security avoids regulatory shortfalls, liability concerns, and international reluctance to permit armed merchant vessels into their ports.").

119. See Foreign AfFAirs COMMITTEe 2012 Report, supra note 7, ๆ 26.

120. Id. $\llbracket 27$.

121. Arabella ThORP, House of COMmOns Library, StANDARD Note SN06237, Preventing AND Prosecuting PIRACy AT SEA: Legal Issues 11 (Feb. 28, 2012), available at http://www.parliament.uk/briefing-papers/SN06237. 
guards on ships may not only lead to an escalation of violence but may also "just encourage pirates, in acts of desperation, to arm themselves more."122 Other commentators are willing to assume that having armed security on board may actually deter pirates from striking that particular ship so as to avoid a potentially deadly fight. ${ }^{123}$ They point out, however, that other ships without such protection may then be especially and unfairly vulnerable to pirate attacks. ${ }^{124}$

Ship owners that hire private armed guards also face the additional complication of having to comply with flag and port state regulations on the carriage and transport of weapons. ${ }^{125}$ For example, South Africa recently announced that it will not allow ships travelling through its waters to carry private armed guards; only military personnel will be allowed to provide protection on ships. ${ }^{126}$ In Seychelles, police board commercial ships and lock the weapons armory. ${ }^{127}$ In Mauritius, ships must release any onboard weapons to the local police to be stored. ${ }^{128}$ In fact, some commentators have described the need to comply with varying and shifting state weapons laws as one of the greatest burdens faced by ships seeking to use armed security personnel for protection and the reason why some private security companies are stocking "floating armories" on the high seas. ${ }^{129}$ Yet such "floating armories" operate in a legal gray area without any international or national regulations governing their use, resulting in concerns that the companies using them are not applying minimum safety standards when storing arms and ammunition. ${ }^{130}$ Estimates as of mid-2012 indicate that approximately 18 vessels were operating as "floating armories" on the high seas, ${ }^{131}$ carrying approximately 7,000 weapons. ${ }^{132}$

122. FOREIGN AFFAIRS COMMITTEE 2012 REPORT, supra note 7, 927.

123. Id.

124. Id. $ๆ 28$.

125. See Volkle Testimony, supra note 118, at 3-4 (describing the challenges of complying with multiple licensing schemes); FOREIGN AFFAIRS COMMITTEE 2012 REPORT, supra note 7, $\uparrow 41$ (same).

126. Aislinn Laing, South Africa Wrecks UK Anti-Piracy Plan, Daily TELEgRAPH (UK), Apr. 23, 2012, at 16 .

127. Mark Lowe, Floating Armouries, MAR. SECURITY REV. (Mar. 13, 2012), http://www.marsecreview.com/2012/03/floating-armouries/.

128. Id.

129. See, e.g., Katharine Houreld, APNewsbreak: Piracy Fighters Using Floating Armories, BLOOMBERG BuSINESSWEEK (Mar. 22, 2012, 12:00 PM ET), http://www.businessweek.com/ap/201203/D9TLKOVO0.htm; Issues Arising from the Use of Armed Guards, supra note 82.

130. U.N. Monitoring Group on Somalia and Eritrea, Rep., transmitted by letter dated July 11, 2012 from the Chair of the Security Council Comm. established pursuant to resolutions 751 (1992) and 1907 (2009) concerning Somalia and Eritrea addressed to the President of the Security Council, Annex 5.4, ๆ 10, U.N. Doc. S/2012/544 (July 13, 2012) [hereinafter U.N. Doc. S/2012/544].

131. Id. ๆ9. 
There are additional reasons to be wary of wholly embracing private armed guards as the potential solution to the maritime piracy problem. Although guards may be able to repel attacks, concerns have been raised about "cowboy" security companies engaging in illegal activities. ${ }^{133}$ The evidence suggests, for example, that the PMSCs are operating the "floating armories," causing potential threats to lives, peace, and security by not properly securing those weapons. ${ }^{134}$ By contrast, when the Netherlands hires out its VPDs, it makes arrangements for the legal transport of weapons. For example, Singapore has agreed that the Netherlands' VPDs may store weapons in Singapore's port. ${ }^{135}$

Others argue that untrained guards operating on the high seas are shooting indiscriminately and unnecessarily killing pirates and innocent fishermen. ${ }^{136}$ Indeed, the belief that government military personnel are well-trained and prepared to act lawfully or face the necessary consequences is one reason why some industry representatives and states have shown a preference for using them in the fight against piracy. ${ }^{137}$ After all, as Admiral Baumgartner pointed out in his testimony before Congress, when one brings armed guards on board a vessel, one must make sure they are "fully qualified ... [and that they have a] well thought-out, wellcoordinated and rehearsed practice method" of using their weapons. ${ }^{138}$ Yet not all private guards are necessarily well-trained, ${ }^{139}$ and in any event, private guards do not operate under a military chain of command or subject to military discipline when hired to protect an individual ship.

In addition, no international standard governs the level of force that guards may use to repel a pirate attack. Generally speaking, because

\section{Id. 4 .}

133. FOREIGN AfFAirs COMMITTEe 2012 RePORT, supra note 7, ๑ 39; see also Alice Priddy \& Stuart Casey-Maslen, Counter-Piracy Operations by Private Maritime Security Contractors: Key Legal Issues and Challenges, 10 J. INT'L CRIM. JUST. 839, 842 (2012) (observing that all PMSCs may not be of the same professional caliber); Nikki Gee, Should Armed Guards Defend Ships Against Piracy, MOVER (June 27, 2011), http://www.themover.co.uk/international-news/2011/06/27/should-armedguards-defend-ships-against-piracy (quoting a representative of Royal United Services Institute for Defence and Security as questioning the trustworthiness of some private security companies).

134. U.N. Doc. S/2012/544, supra note 130, 74.

135. Singapore Supports Antipiracy Mission in Gulf of Aden, NeTH. MinisTRY OF DEF. (Mar. 8, 2012, 12:00), http://www.defensie.nl/english/latest/news/2012/03/08/48193981/Singapore_supports_ antipiracy_mission_in_Gulf_of_Aden.

136. Bockmann \& Katz, supra note 14.

137. Volkle Testimony, supra note 118, at 2; FOREIGN AFFAIRS COMMITTEE 2012 RePORT, supra note 7, ๆ 25.

138. International Piracy on the High Seas: Hearing before the Subcomm. on Coast Guard and Mar. Transp. of the H. Comm. on Transp. and Infrastructure, 111 th Cong. 12 (Feb. 4, 2009) (statement of Rear Admiral William D. Baumgartner, Judge Advocate General, United States Coast Guard).

139. Bockmann \& Katz, supra note 14. 
PMSC personnel are private citizens, they may only use lethal force to stop a pirate attack in self-defense or defense of others. ${ }^{140}$ Guards must look to flag state law and the law of the territories in which they operate to determine precisely what conduct by alleged pirates will suffice to trigger the right to respond with lethal force and what steps guards must take, if any, before responding with such force. ${ }^{141}$ Any use of excessive and unauthorized force will subject the guards to potential criminal and civil liability - in the flag state and in the state where they used force. ${ }^{142}$ Thus, at present, even if the guards are correct that any use of force was proper under the laws of the flag state, the territorial state could conclude that those same actions violated its laws.

It is true that states sometimes waive their rights to assert jurisdiction over particular actors and conduct by way of grants of immunity. ${ }^{143}$ In the context of the fight against maritime piracy, such immunity probably only applies to military personnel acting in the course of their official duties. For example, states often enter into Status of Forces Agreements (SOFAs), which are treaties between states that typically grant the state sending military personnel into another state's territory primary concurrent jurisdiction over offenses committed by its personnel while acting in the line of duty. ${ }^{144}$ But PMSC personnel are private citizens and therefore are

140. Priddy \& Casey-Maslen, supra note 133, at 844-45.

141. See Foreign AfFAIRS COMMITTEe 2012 RePORT, supra note 7, ๆ 34 (stating that private armed security on vessels flagged in the United Kingdom must comply with UK laws on the use of force).

142. General principles of international law also likely allow a state to exercise jurisdiction over crimes committed on the high seas that began on a ship flagged by another state but concluded on the state's own flagged ship. See Joseph William Davids, Jurisdiction and Diplomacy on the High Seas: India vs. Italy, \{NEW\} INT'L L. (Feb. 29, 2012, 10:59 PM), http://thenewinternationallaw.wordpress .com/2012/02/29/jurisdiction-and-diplomacy-on-the-high-seas-india-vs-italy/ (noting that Italy disputes India's power to exercise jurisdiction over the Enrica Lexie marines if the shooting occurred on the high seas but suggesting that under international law, the "objective" territorial principle allows a state to exercise jurisdiction over crimes occurring on the high seas that began on another country's flagged ship but ended on the state's own flagged ship); see also Douglas Guilfoyle, Shooting Fisherman Mistaken for Pirates: Jurisdiction, Immunity, and State Responsibility, EJIL: TALK! (Mar. 2, 2012), http://www.ejiltalk.org/shooting-fishermen-mistaken-for-pirates-jurisdiction-immunity-and-state-

responsibility/ (explaining a general principle of international law that an "offence commenced on a vessel of flag State A which has fatal consequences aboard the vessel of flag State B can be subject to the criminal law of both A and B.").

143. See generally Joseph William.Davids, India v. Italy Part Four: Functional Immunity, $\{$ NEW $\}$ INT'L L. (June 26, 2012, 10:59 PM), http://thenewinternationallaw.wordpress.com/2012/06/18/india-vitaly-part-four-functional-immunity/ (describing the origins of functional immunity).

144. David Scheffer, The Constitutionality of the Rome Statute of the International Criminal Court, 98 J. CRIM. L. \& CRIMINOlogy 983, 1013 (2008); see also Richard J. Erickson, Status of Forces Agreements: A Sharing of Sovereign Prerogative, 37 A.F. L. REV. 137, 139-40 (1994) (describing the U.S. practice of entering into SOFAs). 
not entitled to special immunity from foreign suits should they use excessive force to repel what they believe is a pirate attack. ${ }^{145}$

Even so, the outcome of the Enrica Lexie shooting incident shows that military personnel hired out in their private capacity may not be granted immunity from another state's exercise of criminal jurisdiction over their activities either. That shooting involved trained Italian marines who were part of a government-offered VPD but whom the Indian government claims killed innocent fishermen without provocation. ${ }^{146}$ On the question of jurisdiction, the Italian government has argued that the marines are entitled to functional immunity from foreign prosecution because they were acting as an organ of the Italian state and because the shooting occurred in international waters. ${ }^{147}$ The Indian government has rejected that argument, asserting instead that it has jurisdiction over the shooting offense because the marines shot Indians on an Indian boat. ${ }^{148}$ The Italian government recently settled civil charges brought on behalf of the dead fisherman-for reported sums of $\$ 180,000$ each. $^{149}$ As of mid-December 2012, however, criminal charges against the two marines remained pending. ${ }^{150}$ Accordingly, the Enrica Lexie incident demonstrates that not all states will necessarily conclude that military personnel hired to provide private protection for a commercial vessel are immune from prosecution for violating the state's criminal laws.

Finally, adding private armed guards to a ship can create additional issues about when, and how, the use of force may be authorized and who may be liable for any excessive use of force. ${ }^{151}$ On the one hand, the armed guards are tasked with repelling pirate attacks and likely believe that a decision on whether to use lethal force should rest with the security team. ${ }^{152}$

145. See Priddy \& Casey-Maslen, supra note 133, at 844-45 (noting that PMSCs are private citizens and thus subject to criminal prosecution if they use unlawful force).

146. Alan Katz, Brother Shot Dead Fishing Tests Armed Guards'Accountability, BLOOMBERG (Nov. 28, 2012, 7:01 PM ET), http://www.bloomberg.com/news/2012-11-29/brother-shot-dead-fishingtests-armed-guards-accountability.html.

147. Gayathri, supra note 116; Hari Sankar, Jurisdictional and Immunity Issues in the Story of Enrica Lexie: Shoot \& Scoot Turns Around!, EJIL: TALK! (Mar. 25, 2013), http://www.ejiltalk.org/ jurisdictional-and-immunity-issues-in-the-story-of-enrica-lexie-a-case-of-shoot-scoot-turns-around/.

148. Sankar, supra note 147.

149. Katz, supra note 146.

150. Enrica Lexie Case: Italy Summons Indian Envoy, SIFYNEWS (Dec. 14, 2012, 17:36), http://www.sify.com/news/enrica-lexie-case-italy-summons-indian-envoy-news-internationalmmoqPsjhbei.html.

151. See Issues Arising from the Use of Armed Guards, supra note 82 (describing the need for clear Rules of Engagement, the prudence of informing various parties of the intent to hire private guards, and the possibilities of liability in the event of a hijacking).

152. Id. (noting that the security team may contractually have discretion over whether and when 
On the other hand, international regulations and longstanding practice rest ultimate authority for the safety of life at sea with the ship's captain. ${ }^{153}$ Further, there is reason to believe many captains would not be comfortable ceding such authority, a point made by Captain Richard Phillips, whose ship, the Maersk Alabama, was attacked by pirates. Before the Senate Foreign Relations Committee, he stated: "I am not comfortable giving up command authority to others ... including the commander of a protection force. In the heat of an attack, there can be only one final decision maker." 154 Yet, if command authority is not agreed on clearly and in advance, chaos could ensue during a pirate attack, and attempts to shift blame would likely follow any assertions that the force used exceeded what was necessary.

\section{The Maritime Industry's Evolving Stance on Private Armed Guards}

For many of the reasons discussed above, until 2011 the maritime industry generally opposed the use of private armed guards on ships. ${ }^{155}$ Naval forces were charged with providing the bulk of anti-piracy protection, and individual ships were encouraged to assist in deterring piratical acts by following the industry's "best management practices"- a set of guidelines outlining a host of primarily passive defensive measures. ${ }^{156}$ For example, the guidelines cautioned ships to install, among

lethal force is used).

153. According to the IMO's International Convention for the Safety of Life at Sea (SOLAS), Regulation 34-1, "[t]he owner, the charterer, the company operating the ship as defined in regulation IX/1, or any other person shall not prevent or restrict the master of the ship from taking or executing any decision which, in the master's professional judgment, is necessary for the safety of life at sea and protection of the marine environment." United Nations International Convention for the Safety of Life at Sea, Annex, Ch. V, Regulation 34-1, concluded Nov. 1, 1974, 34 U.S.T. 47 (amended by M.S.C. Res. 153(78) (May 20, 2004)), available at http://www.unhcr.org/refworld/pdfid/432aca724.pdf. This same idea is echoed in the International Ship and Port Facility Security Code (ISPS), which was implemented in 2004 as part of a new SOLAS chapter to enhance maritime security. The ISPS requires that the captain have the ultimate responsibility for the safety and security of the ship. See Diplomatic Conference on Maritime Security, IMO, International Ship and Port Facility Security Code, Annex I, Part B, sec. 4.10, IMO Doc. SOLAS/CONF.5/24 (Dec. 12, 2002).

154. Confronting Piracy off the Coast of Somalia: Hearing before the S. Comm. on Foreign Relations, 111th Cong. 6 (2009) (statement of Captain Richard Phillips, Master of the Maersk Alabama).

155. See, e.g., IMO, Piracy and Armed Robbery against Ships: Recommendations to Governments for Preventing and Suppressing Piracy and Armed Robbery against Ships, Annex 9 4, IMO Doc. MSC.1/Circ. 1333 (June 26, 2009) (noting concerns about having to comply with state laws on weapons carriage and the risks associated with having weapons around flammable or dangerous cargo); id. 97 (discussing the risks of escalating violence if weapons are allowed on board ships).

156. See, e.g., IMO, Piracy and Armed Robbery against Ships in Waters off the Coast of Somalia: Best Management Practices to Deter Piracy off the Coast of Somalia and in the Arabian Sea Area Developed by the Industry, Annex II, - 6.11, IMO Doc. MSC.1/Circ. 1337 (Aug. 4, 2010) [hereinafter 
other things, alarms, motion detectors, and closed circuit televisions, so as to be warned of imminent attacks. ${ }^{157}$ The guidelines also counseled ships on the use of non-lethal defensive tools, such as high-powered fire hoses and razor wire barriers that can repel pirates trying to board a ship. ${ }^{158}$ In addition, suggested best management practices prompted ships to register with international and regional monitoring agencies so that navies and other government-sponsored counter-piracy teams would be able to provide assistance if needed. ${ }^{159}$

The fact that the world's navies were unable to protect every ship from experiencing an act of piracy, however, resulted in ship owners calling for the right to hire private armed guards to accompany them when travelling through pirate-infested waters. ${ }^{160}$ Those calls were essentially heeded in early 2011 when the International Chamber of Shipping (ICS), which represents national ship owners' associations from over 30 countries, announced that it had changed its previous stance opposing the use of armed guards on ships. ${ }^{161}$ Instead, it concluded that the decision as to whether armed security can participate in the fight against maritime piracy should be a matter for flag states to decide. ${ }^{162}$ The ICS chairman explained:

ICS has had to acknowledge that the decision to engage armed guards, whether military or private, is a decision to be made by the ship operator after due consideration of all of the risks, and subject to the approval of the vessel's flag state and insurers. The consensus view amongst shipping industry associations remains that, in normal circumstances, private armed guards are not recommended, and are a clear second best to military personnel. However, in view of the current crisis in the

Circ. 1337] (revoking and replacing Circular 1335) ("The use of additional private security guards is at the discretion of the company, but the use of armed guards is not recommended."); IMO, Piracy and Armed Robbery against Ships in Waters off the Coast of Somalia: Best Management Practices to Deter Piracy in the Gulf of Aden and off the Coast of Somalia, Annex II, at 4, IMO Doc. MSC.1/Circ. 1335 (Sept. 29, 2009) [hereinafter Circ. 1335] (stating that ships could hire private security but that "the use of armed guards is not recommended").

157. Circ. 1337, supra note 156, Annex II, § 9; Circ. 1335, supra note 156, Annex II, at 7.

158. Circ. 1337, supra note 156, Annex II, § 9; Circ. 1335, supra note 156, Annex II, at 7.

159. E.g., Circ. 1337, supra note 156, Annex II, § 6; Circ. 1335, supra note 156, Annex III, at 1; see also FOREIGN AFFAIRS COMMITTEE 2012 REPORT, supra note 7, ๆ 24 (generally describing some best management practice guidelines); Lang Report, supra note 24, ๆ 34 (describing best management practices as defined by the maritime community).

160. FOREIGN AFFAIRS COMMITTEE 2012 REPORT, supra note 7, ๆ 25.

161. ICS Changes Position on Using Armed Guards to Protect Ships against Pirates, MARINELOG (Feb. 15, 2011), http://www.marinelog.com/index.php?option=com_k2\&view=item\&id=505:icschanges-position-on-using-armed-guards-to-protect-ships-against-pirates\&Itemid=231.

162. Id. 
Indian Ocean - with over 700 seafarers held hostage and, most recently, a seafarer being executed-ship operators must be able to retain all possible options available to deter attacks and defend their crews against piracy. Many shipping companies have concluded that arming ships is a necessary alternative to avoiding the Indian Ocean completely, which would have a hugely damaging impact on the movement of world trade. ${ }^{163}$

The IMO followed the ICS by issuing a series of Circulars beginning in May 2011 that cautiously endorsed a regime whereby flag states would be able to decide whether and under what circumstances armed security personnel should be allowed on their ships. In its guidance, the IMO emphasized that the use of private armed security should not be considered an alternative to best management practices and other, more passive, measures to defend against pirate attacks. ${ }^{164}$ It also emphasized the need to minimize the risks associated with placing armed guards on ships through the use of clear flag state policies. In particular, the IMO encouraged flag states to develop and employ: (1) a process for authorizing ship owners' use of private guards, (2) mechanisms for ensuring accountability with the terms and conditions under which any authorization to hire guards would be granted, (3) information about the lawful carriage and use of firearms by private guards, (4) guidance on command authority as between the captain and any armed security, and (5) reporting and recordkeeping requirements. ${ }^{165}$ By September 2011, shipping industry representatives had drafted an updated version of the best management practices (BMP4) similarly acknowledging that whether to use armed guards on "merchant vessels is a matter for individual ship operators to decide following their own voyage risk assessment and approval of respective Flag States."166

In May 2012, in an effort to enrich existing advice, the IMO also issued interim guidance to PMSCs. ${ }^{167}$ That guidance, among other things, encourages PMSCs to acknowledge the need to operate according to flag state and other applicable laws. ${ }^{168}$ It recommends that firms only hire out

163. Id.

164. Circ. 1405, supra note 11, Annex, $₫ 1$.

165. Circ. 1406, supra note 11, Annex, at 1-2. For the IMO's updated recommendations, see IMO, Revised Interim Guidance for Flag States Regarding the Use of Privately Contracted Armed Security Personnel on board Ships in the High Risk Area, IMO Doc. MSC.1/Circ. 1406/Rev. 2 (May 25, 2012).

166. IMO, Piracy and Armed Robbery against Ships in Waters off the Coast of Somalia: Best Management Practices for Protection against Somalia Based Piracy, at 2, IMO Doc. MSC.1/Circ. 1339 (Sept. 14, 2011) [hereinafter BMP4] (revoking and replacing Circular 1337 from 2010).

167. Circ. 1443, supra note 7.

168. Id. Annex, ๆ 1.3. 
personnel who are trained to operate in a maritime context and that the firms carry adequate insurance to cover any claims that might arise as a result of their employees' conduct. ${ }^{169}$ The guidance cautions that personnel acting as armed guards must abide by flag state and other laws regarding the carriage and use of firearms and to also recognize that laws regarding the use of lethal force vary from state to state. ${ }^{170}$ In addition, the guidance further recommends that PMSCs respect that the captain is in control of the ship. ${ }^{171}$

\section{PRIVATE ARMED GUARDS ON SHIPS: A COMPARISON OF SOME FLAG STATE APPROACHES}

As the above discussion indicates, whether to allow private armed guards on ships to assist in the fight against maritime piracy is a complex question. It is also one to which the answers of flag states differ. ${ }^{172}$ Even after the ICS and IMO withdrew their objections to armed guards in 2011, some states have remained opposed to the idea. Indonesia, for instance, has stated that it will consistently oppose proposals to allow recruiting private armed security guards on ships because of, among other things, the absence of national and international legal instruments governing their hiring and conduct. $^{173}$ As noted above, the Netherlands' policy only allows Dutch flagged ships to be protected by military personnel that the country hires out to commercial ship owners. ${ }^{174}$

Many states, though, have recently changed their laws, or are considering changing them, to allow their ship owners to hire private armed guards. ${ }^{175}$ The United Kingdom is a good example of a state that recently reversed its stance on the issue. In July 2011, the government strongly discouraged the use of private armed guards and instead backed naval

169. Id. Annex, $\uparrow \uparrow 1.5,3.4,3.8$.

170. Id. Annex, ๆๆ 3.3, 5.13.

171. Id. Annex, $₫ 5.6$.

172. See InT'L Chamber of Shipping [ICS] \& EuRopeAn CMTy. Shipowners Ass'ns [ECSA], COMPARISON OF FlaG STATE LAWS ON ARMED GUARDS AND ARMS ON BOARD (2013), available at http://www.ics-shipping.org/docs/default-source/Piracy-Docs/comparison-of-flag-state-laws-on-armedguards-and-arms-on-board.pdf [hereinafter ICS Flag State Comparison].

173. Ridwan Max Sijabat, RI Says No to Private Armed Guards aboard Vessels, JAKARTA POST (June 13, 2012, 10:40 AM), http://www.thejakartapost.com/news/2012/06/13/ri-says-no-private-armedguards-aboard-vessels.html.

174. Stares, supra note 112.

175. See, e.g., Brown, supra note 7, at 17 (reporting that since 2011 India, Liberia, Panama, Greece, Norway, Cyprus, Denmark, France, Egypt, and the Philippines have changed their laws to allow for private armed security on board their ships and that several other countries are considering doing the same). 
patrols and the use of best management practices on board ships. ${ }^{176}$ On October 30, 2011, however, the Prime Minister announced that the UK would allow its ship owners to hire private security forces. ${ }^{177}$ The Written Ministerial Statement that followed in December explained that guards would be allowed under "exceptional circumstances" and only when the ship is travelling in the areas posing the highest risk of pirate attacks. ${ }^{178}$ Other states, including Cyprus, ${ }^{179}$ Denmark, ${ }^{180}$ and Greece, ${ }^{181}$ have also changed their laws since 2011 to allow for armed security on board their flagged ships. In June 2011, Norway announced a new framework for the use of armed security personnel on its ships. ${ }^{182}$ Belgium, ${ }^{183}$ France, ${ }^{184}$ Germany, ${ }^{185}$ and Japan ${ }^{186}$ are among the states that have indicated they are

176. FOREIGN AFFAIRS COMMITTEE 2012 REPORT, supra note 7, 931.

177. Id.

178. Id. $₫ 32$.

179. ICS Flag State Comparison, supra note 172, at 2 (reporting that Cyprus has passed a bill allowing for armed guards); see also Cyprus: Ships Need Armed Guards, MARITIMESECURITY.ASIA (May 18, 2012), http://maritimesecurity.asia/free-2/piracy-2/cyprus-ships-need-armed-guards/ (reporting that Cypriot lawmakers were discussing a bill to allow private armed guards on board Cyprus-flagged ships).

180. Piracy, Policies and Strategies, DANISH MAR. AuTH., http://www.dma.dk/Policy/Sider/Piracy .aspx (last visited Sept. 20, 2013) (stating that Denmark now allows ships to employ armed guards under some circumstances).

181. Greek Parliament Ratifies Legislation Introducing Armed Guards aboard Vessels, SHIPPING Herald: The Mar. PORTAL (Mar. 15, 2012), http://www.shippingherald.com/Admin/ArticleDetail/ tabid/94/ArticleID/3481/Greek-Parliament-ratifies-legislation-introducing-armed-guards-aboardvessels.aspx.

182. National Regulations on the Use of Armed Guards, SKULD, https://extranet.skuld.com/Insight/ Piracy/Armed-Guards/National-regulations-on-the-use-of-armed-guards/ (last visited Sept. 15, 2013).

183. Belgium Moves to Regulate Vessels' Private Armed Guards, LlOYD's LIST (May 18, 2012, 12:59), http://www.1loydslist.com/11/sector/ports-and-logistics/article398587.ece.

184. ICS Flag State Comparison, supra note 172, at 3. Until 2012, France only allowed its ships to be guarded by military teams provided by the state. But under pressure from ship owners, France is drafting a law to allow them to employ guards from PMSCs. Id.; see also Valerie Gabard, Privately Contracted Armed Security Personnel and Counter-Piracy: Is France at a Turning Point?, COMMUNIS Hostis OMNIUM (Apr. 17, 2012), http://piracy-law.com/2012/04/17/privately-contracted-armedsecurity-personnel-and-counter-piracy-is-france-at-a-turning-point/.

185. See ICS Flag State Comparison, supra note 172, at 3 (stating that the German government has drafted a bill to allow ships to hire private armed guards to serve on commercial ships under certain circumstances); Germany Seeks EU Support of Plan to Combat Piracy, EdMOnTON J., Aug. 24, 2011, at C.2, available at http://www2.canada.com/edmontonjournal/news/business/story.html?id=4517f0278d8c-46a4-80b3-72ecb0b59b06 (reporting that the German government was considering changing its laws to allow its ships to carry private armed security personnel in areas that pose a high risk of pirate attacks).

186. Antipiracy Bill Drafted to let Private Armed Guards Defend Ships, THE JaPAN Times, Feb. 4, 2013, available at http://www.japantimes.co.jp/news/2013/02/04/national/antipiracy-bill-drafted-to-letprivate-armed-guards-defend-ships/\#.Uj0eZWTwJMI (reporting that Japan has a new draft law to allow its ships to carry private armed security guards under some circumstances). 
considering implementing new laws to permit private armed guards.

But under what circumstances are states allowing these private actors to participate in a fight that was until recently reserved for military personnel operating as part of a United Nations-sanctioned mission? Are states regulating, licensing, or monitoring these private actors who will wield guns on the world's shared oceans? Are they regulating how these private actors carry and transport weapons or specifying permissible sources from which the guards may obtain their weapons? Are states providing these private actors with any special guidance on the use of force or on who may authorize its use? Even if individual states are regulating or providing guidance on any of these matters, are state policies coordinated and uniform? After all, the fight against piracy occurs in an international arena. Shouldn't all states want to ensure that the private citizens engaging in actions once reserved for military personnel are subjected to some training and monitoring?

This Article examines the laws and guidance of five different states as they relate to hiring armed guards to protect ships against pirate attacks in an effort to obtain some answers to these questions. The first section identifies the states chosen for inclusion in the study and their general approaches toward regulating the use of private armed guards on ships travelling through pirate-infested waters. The remaining sections compare and synthesize various aspects of the states' laws and guidance to facilitate a discussion about whether the current approaches are sufficient to mitigate some of the risks associated with allowing private citizens to participate in the fight against piracy.

A. Overview: States Included in the Study and Their General Approaches to Regulating the Use of Private Armed Guards

This Article uses the laws and guidance of (1) the United States, (2) the United Kingdom, (3) Denmark, (4) Norway, and (5) Singapore to explore some approaches that states have taken to regulating the use of private armed guards on their ships. There are several reasons for focusing on these five states. First, these states all have strong shipping interests. As of December 2010, the United States, the United Kingdom, Norway, Denmark, and Singapore were each listed among the states with parent companies owning the top twenty controlled merchant fleets in terms of gross tonnage. ${ }^{187}$ Second, including the United States and the United

187. IMO, International Shipping Facts and Figures - Information Resources on Trade, Safety, Security, Environment $\S 3.7$ (Mar. 6, 2012), available at http://www.imo.org/KnowledgeCentre/ ShipsAndShippingFactsAndFigures/TheRoleandImportanceofInternationalShipping/Documents/Interna 
Kingdom in the study is important, as both are states from which a number of PMSCs hail - meaning that both should have a relatively great interest in regulating PMSC conduct. ${ }^{188}$ Third, these states authorize the use of private armed guards in different ways, thus facilitating a later comparison of approaches and a discussion of their strengths and weaknesses. Finally, as a practical matter, information about these states' laws and guidance is available in English, thereby obviating the need to translate from another language.

Although each of these states has authorized the use of private armed guards on board their commercial ships while travelling through pirateinfested waters, the timing and nature of their commitment to the idea differ in some respects. For example, the United States' acceptance of private armed guards seems relatively long-standing and also quite strong. The United States has authorized personnel on commercial ships to use force to defend against maritime pirate attacks for more than one hundred years. According to 33 U.S.C. $§ 383$, which is entitled "Resistance of pirates by merchant vessels," the commander and crew of any merchant vessels owned in whole or in part by a United States citizen may defend against any attack by another private armed vessel. ${ }^{189}$ How much and what kind of force civilians may use to repel pirate attacks is a topic that is addressed by reference to general law in the area, rather than by any specific language in Section 383. To provide more exact guidance on the topic in the piracy context, in 2009 the United States Coast Guard and the Department of Homeland Security jointly issued a Port Security Advisory entitled Guidance on Self-Defense and Defense of Others by U.S. Flagged Commercial Vessels Operating in High Risk Waters. ${ }^{190}$ That 2009 SelfDefense Advisory "restates existing law" and clarifies the rules to be followed by all vessel personnel, including private security guards, when defending against pirate attacks. ${ }^{191}$

tional\%20Shipping\%20-\%20Facts\%20and\%20Figures.pdf.

188. BROWN, supra note 7, at 6 (stating that most contractors are British or American); Erwin, supra note 8 (stating that about half of the PMSCs providing maritime security services are based in the United Kingdom).

189. 33 U.S.C. $\S 383$ (2012) (original version at R.S. $\S 4295$, enacted as Act of Mar. 3, 1819, ch. $77, \S 3,3$ Stat. 513).

190. U.S. Coast Guard, Dep't of Homeland SeC., Port Security Advisory (3-09):

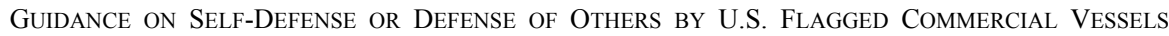
Operating In High Risk Waters (June 18, 2009) [hereinafter PORT SECURITY AdVISORY 3-09]. Port Security Advisory 3-09 specifically states that it anticipates its guidance to apply to contracted security personnel who will serve as guards on or will provide a security escort to a United States vessel while stationed on an accompanying vessel that is flagged by the United States but that is not a government vessel (such as a navy ship). Id. at $1 \mathrm{n} .1$.

191. Id. at 1 (stating that the guidance does not establish new standards or duties regarding the 
March 2012 remarks by Andrew Shapiro, Assistant Secretary of the Bureau of Political-Military Affairs, further demonstrate the United States' commitment to using private armed guards. ${ }^{192} \mathrm{Mr}$. Shapiro explained that the United States permits its commercial vessels to carry private armed security teams. ${ }^{193}$ Because of the seriousness of the threat posed by maritime piracy to the safety of international ships, crews, and cargo, the United States has also encouraged other countries to follow suit. ${ }^{194} \mathrm{Mr}$. Shapiro recognized that employing armed guards may involve some complicated issues. ${ }^{195}$ But he played down concerns of "cowboy" guards, saying that the evidence showed that most private armed guards act responsibly, only firing warning shots after using non-lethal methods, such as flares or loudspeakers, to scare pirates away. ${ }^{196}$ Regarding weapons carriage and transport, he stated that the United States has worked, and will continue to work, with other states to facilitate the legal movement of arms. $^{197}$

The United Kingdom and Denmark, by contrast, have only recently changed their previous stances, now allowing their ship owners to employ private armed guards. As mentioned above, on October 30, 2011, Prime Minister David Cameron announced the United Kingdom's decision to authorize the use of private armed guards under some circumstances. ${ }^{198}$ In announcing the change, the Prime Minister referred to the extent of hijackings for ransom around the Horn of Africa as a "stain" on the world that needed to be tackled. ${ }^{199}$ In December 2011, the government followed with a Written Ministerial Statement outlining the new policy in more detail. $^{200}$ That Statement explained that private armed guards would only

right to use self-defense or to defend others but instead provides examples to illustrate how defense principles might apply in the maritime piracy context).

192. Andrew J. Shapiro, Asst. Sec'y, Bureau of Political-Military Affairs, Remarks to the U.S. Chamber of Commerce: Expanding Private Sector Partnerships Against Piracy (Mar. 13, 2012), available at $\mathrm{http}: / / \mathrm{www}$. state.gov/t/pm/rls/rm/185697.htm.

193. Id.

194. Id.

195. Id.

196. Id.

197. Id.

198. Foreign AfFairs COMmittee 2012 Report, supra note 7, ๆ 21; Somali Piracy: Armed Guards to Protect UK Ships, BBC News, BBC.COM (Oct. 30, 2011, 15:21 ET), http://www.bbc.co.uk/ news/uk-15510467.

199. Thomas Penny, U.K. Ships Allowed Armed Guards Against Piracy, Cameron Says, BlOOMBERG (Oct. 30, 2011, 6:45 AM ET), http://www.bloomberg.com/news/2011-10-30/u-k-ships-tocarry-armed-guards-against-pirates-cameron-says.html.

200. Written Statement to Parliament from Mike Penning, MP, Parliamentary Under-Sec'y of State for Transp., The Use of Private Armed Guards on board UK Registered Ships under Exceptional Circumstances to Defend against Piracy (Dec. 6, 2011), available at https://www.gov.uk/government/ 
be permitted under "exceptional circumstances," defined as where (1) the ship is transiting on the high seas through a specific area posing a high risk of pirate attacks, ${ }^{201}$ (2) the ship is following the latest IMO best management practices but has concluded that they are insufficient to protect it against a pirate attack, and (3) the use of armed guards is likely to reduce the risks to the lives of those travelling on board. ${ }^{202}$ Along with the Statement, the government published its Interim Guidance to UK Flagged Shipping on the Use of Armed Guards to Defend against the Threat of Piracy in Exceptional Circumstances. ${ }^{203}$ The Guidance sets out the government's policy on the use of armed guards on board UK-flagged ships and the rules regarding the use of force, command responsibility, and the carriage and transport of arms. ${ }^{204}$

The Danish government only yielded to ship owners' requests to be allowed to hire armed guards for individualized protection in May 2011. ${ }^{205}$ Prior to that time, the government had strongly opposed the use of private armed guards on board ships flying the Danish flag. ${ }^{206}$ It had been concerned about granting civilians the permission to use weapons in selfdefense and had feared that pirates would only escalate the violence they used to perpetrate their attacks if they knew that ships were carrying armed guards. $^{207}$ Recognizing the increasing difficulty that the world's navies were having in defending against pirate activities that now occur in an expanded geographical range, however, the government changed its policy. ${ }^{208}$ Nevertheless, the Danish government rejected ship owners' requests to employ current military personnel as guards on their ships, stating that using scarce government resources would not be cost effective

speeches/the-use-of-private-armed-guards-on-board-uk-registered-ships-under-exceptionalcircumstances-to-defend-against-piracy [hereinafter Penning Statement].

201. Id. (defining "high risk area" as "an area bounded by Suez and the Straits of Hormuz to the North").

202. Id.

203. DEP'T FOR TRANSP., INTERIM GUIDANCE TO UK FLAGGED SHIPPING ON THE USE OF ARMED

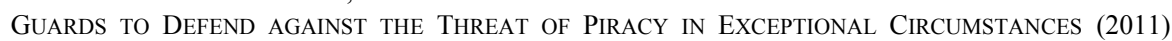
(amended 2012), available at http://assets.dft.gov.uk/publications/use-of-armed-guards-to-defendagainst-piracy/use-of-armed-guards-to-defend-against-piracy.pdf [hereinafter JUNE 2012 INTERIM GUIDANCE].

204. Id. at $6, \S 1$.

205. Ministry of Foreign Affairs, Ministry of Justice, Ministry of Def., Ministry of ECON. AND Bus. AfFAirs, Strategy FOR THE DANISH COUNTER-PIRACY EFFORT 2011-2014, at 25 (May 2011), available at http://um.dk/ /media/UM/English-site/Documents/Politics-and-diplomacy/ Pirateristrategi_2011_ENG_WEB.PDF [hereinafter DANISH STRATEGY].

206. Id.

207. Id.

208. Id. 
and would run counter to the interest in encouraging international cooperation to deter maritime piracy rather than forging a regime whereby each state protects only its own ship owners. ${ }^{209}$

Although it has no general law permitting armed defense of its ships against pirate attacks, Norway has, since 2007, authorized the captain of a Norwegian ship to take actions to defend the vessel, including using private armed guards on board. $^{210}$ In July 2011, the government amended its regulations on ship security and arms carriage to more specifically address the problem of maritime piracy by regulating ships' usage of armed security when travelling in waters known to pose a high risk of pirate attacks. $^{211}$ The government's subsequently-issued Provisional Guidelines offer explanatory comments to aid ship owners in understanding the new regulations. ${ }^{212}$ According to those comments, the new regulations do not encourage the use of private armed security guards but are intended, instead, to regulate the selection and use of such guards so that the highest possible professional and ethical standards are followed when their services are used on Norwegian flagged vessels. ${ }^{213}$

Finally, Singapore does not ban the use of private armed guards on its ships, but at the same time, its endorsement of their use appears cautious. ${ }^{214}$ In its Shipping Circular dated September 18, 2012, Singapore advises that the use of armed guards should not be considered an alternative to the effective employment of best management practices or other more passive

209. Id. at 24 .

210. See ICS Flag State Comparison, supra note 172, at 6; see also Norway Clarifies Ruling on Armed Guard Use, INTERMANAGER (July 1, 2011). http://www.intermanager.org/2011/07/norwayclarifies-ruling-on-armed-guard-use/ (stating that Norway's 2007 law addressed ship security but not the then-unknown threat posed by maritime piracy).

211. Norwegian Mar. Directorate, Regulations COnCERning AMENDMEnts to the Regulations of 22 June 2004 No. 972 Concerning Protective SECurity Measures on board SHIPS AND MOBILE OFFSHORE DRILLING UNITS (SAFETY REGUlATIONS) (July 1, 2011) [hereinafter Norway Amended Safety Regulations], available at http://www.skuld.com/upload/News\%20and\%20 Publications/Publications/Piracy/Regulations_concerning_amendments_to_the_Regulation_of_22_June 2004_nr.972.pdf. The new regulations are now entitled Regulations of 22 June 2004 No. 972 Concerning Security, Anti-Terrorism and Anti-Piracy Measures and the Use of Force on board Ships and Mobile Offshore Drilling Units (the Security Regulations). Id.

212. Norwegian Mar. Directorate, Provisional Guidelines-USE of Armed Guards on BOARD NORWEGIAN SHIPS (July 2011), available at http://www.skuld.com/upload/News\%20and\%20 Publications/Publications/Piracy/Provisional_guidelines_The_use_of_armed_guards_onboard_Norwegi an_ships.pdf [hereinafter Norway Provisional Guidelines].

213. Id. at 2. Recent figures indicate that about $30 \%$ of Norwegian vessels operating off the coast of Somalia have employed armed personnel from PMSCs to protect them against maritime piracy. Valeria Criscione, Norway Responds to Increased Piracy Attacks, NORTRADE.COM (Aug. 10, 2012), http://www.nortrade.com/sectors/articles/norway-responds-to-increased-piracy-attacks/.

214. See ICS Flag State Comparison, supra note 172, at 6. 
defensive measures to guard against maritime piracy. ${ }^{215}$ It also notes that the decision of whether to hire such armed security personnel is a matter for ship owners and operators. ${ }^{216}$ Nevertheless, it warns that the decision should be made "after a thorough risk assessment and after ensuring all other practical means of self protection have been employed." ${ }^{217}$ Singapore refers ship owners and operators to the IMO's Circular for a list of the factors and considerations that should guide such risk assessment. ${ }^{218}$

The sections that follow explore and compare several specific aspects of the laws and guidance of these five states as they relate to the various risks that have been previously identified as being associated with permitting private guards to aid in the fight against piracy.

\section{B. Laws and Guidance to Regulate the PMSC Industry or Vet Guards}

One risk associated with using private armed guards in the fight against piracy is that not all will be well-trained and prepared to act in a lawful and proper manner when defending ships against attacks. To the extent that states want to guard against such risks, they might regulate the PMSC industry or in some way vet the guards that ship owners are permitted to hire. A review of the laws and guidance of the five states that are the subject of this study, however, indicates that at least these states are not willing to undertake such tasks. For the most part, these states have gone on record and cautioned ship owners to be diligent when hiring guards but have otherwise made clear that they are not in the business of passing on the competence of the guards that their ship owners hire.

For example, the United States warns ship owners that any security personnel hired by U.S. flagged ships must be fluent in English and must also meet certain training requirements enabling them to effectively defend the vessel and crew while in high risk waters and in accordance with the approved protection plan for the vessel. ${ }^{219}$ In addition, it cautions that any security personnel should be trained in the use of any firearms that they are carrying, weapons safety, and the lawful use of force in self-defense and

215. Mar. And Port Auth. Of Sing., ShipPing Circular No. 15 OF 2012, at 1 (Sept. 18, 2012), available at http://www.mpa.gov.sg/sites/pdf/sc15-12.pdf. Shipping Circular No. 15 replaces a similar Shipping Circular No. 11, which was issued in June 2011. MAR. AND PORT AUTH. OF Sing., SHIPPING CIRCUlAR NO. 11 OF 2011 (June 10, 2011), available at http://www.mpa.gov.sg/sites/circulars_and_ notices/pdfs/shipping_circulars/sc_no_11_of_2011.pdf.

216. Id. at $1-2$.

217. Id.

218. Id. at 2 .

219. U.S. CoAst Guard, Dep'T of Homeland SeC., Port SeCurity Advisory (5-09) (ReV 1): MiNIMUM GUIDELINES FOR CONTRACTED SECURITY SERVICES IN HIGH RISK WATERS $\uparrow$ ๆ 7, 11 (July 24 2009) (referencing the training requirements in 33 C.F.R. 104.220 (2007)). 
defense of others. ${ }^{220}$

The United Kingdom only allows ship owners to hire armed guards if the owners file with the government a counter-piracy plan indicating why this extra level of protection, beyond following best management practices, is necessary. ${ }^{221}$ And it reminds ship owners that the presence of armed security personnel could lead to an escalation of violence. ${ }^{222}$ Nevertheless, the government notes that it has no accreditation process for PMSCs and warns ship owners to be "extra vigilant" in selecting the company from which to hire security personnel. ${ }^{223}$ The only other protection against the possibility of untrained, "cowboy" guards operating on the high seas is the government's outline of the types of due diligence that ship owners should undertake when selecting a PMSC. ${ }^{224}$

The new Danish counter-piracy strategy gives ship owners the possibility of applying for a firearms certificate to use armed security on board Danish ships as long as it is perceived necessary based on the general threat assessment for the area "and as long as the specifics of the case, also in terms of compliance with Best Management Practices, do not otherwise speak against it." ${ }^{225}$ According to the government, the intention is to make the application process as flexible as possible, while at the same time "ensuring that no available personal data on the guards gives cause for concern when issuing a firearms certificate." 226 Ship owners must provide the government with various items of information to obtain the firearms certificate. They must identify the PMSC and the specific guards they intend to hire and provide those guards' certificates of criminal record, information on their training and experience in arms operation, and copies of any valid arms licenses. ${ }^{27}$ In addition, ship owners must identify the specific weapons to be brought on board the vessel and whether the arms will be carried out of and into Denmark. ${ }^{228}$ Nevertheless, Denmark does not oversee any vetting process for guards, instead leaving the ship owner

220. $I d . ~ ๆ 7$.

221. JUNE 2012 INTERIM GUIDANCE, supra note 203, $§ 2.10$.

222. Id. $\S 2.7$.

223. Id. $\S 1.8$.

224. Id. $\S 3$.

225. DANISH STRATEGY, supra note 205, at 25.

226. Id.

227. Civil and Police DeP'T, Ministry of Justice, Doc. No. IBM40881, Information That SHOULD ACCOMPANY A SHIPPING COMPANY'S APPLICATION FOR USING ARMED CIVILIAN GUARDS ON BOARD DANISH SHIPS, available at http://www.dma.dk/SiteCollectionDocuments/CMR/Piracy/pirateriJM\%20vejledning.pdf.

228. Id. 
to determine the guards' suitability. ${ }^{229}$

Similar to the United Kingdom, Norway requires its ship owners to conduct a risk assessment of passive and active unarmed measures and consult with the ship's captain before deciding to hire armed guards. ${ }^{230}$ In addition, any ship owner that hires armed security to protect its ships must provide certain documentation to the Norwegian Maritime Directorate outlining the reasons why more passive defensive measures will not be adequate, the suitability and qualifications of the security firm and the particular guards to be hired, and the procedures for safely handling and storing firearms and ammunition. ${ }^{231}$ The documentation is designed to make companies employ due diligence in selecting a security firm and provide the government with some necessary information should it later need to investigate any alleged unlawful use of force. ${ }^{232}$ The government, however, specifically states that it is under no duty to conduct a quality check on security firms and will only disqualify a security company if it has received specific and credible information showing that the firm is clearly unsuitable. ${ }^{233}$

Finally, Singapore simply refers its ship owners to the non-binding guidance contained in the various IMO Circulars, including one that details some due diligence in which ship owners should engage before hiring a PMSC company. ${ }^{234}$

\section{Laws and Guidance on the Use of Force}

There is also some concern that private guards may not be aware of or be willing to comply with applicable rules regarding the appropriate use of force. As described below, the evidence indicates that some states are providing some information about when guards may use deadly force. On the other hand, the comparison of state laws also shows that states are not uniform in their guidance and that some guidance is more detailed than others. States seem to be aware that guards may be subject to the laws of different jurisdictions depending on where and under what circumstances

229. Id.; see also Ministry of Justice, No. 698, ORder ON THE USE OF Civilian, ARMED GUARDS ON DANISH CARGO SHIPS $§ 7$ (June 27, 2012), available at http://www.dma.dk/SiteCollection Documents/Legislation/Orders/2012/BEK-698-27062012-brug\%20af\%20civile\%20bev\%C3\%A6bnede $\% 20$ vagter $\% 20 \mathrm{p} \% \mathrm{C} 3 \% \mathrm{~A} 5 \% 20$ danske\%20lastskibe.pdf (establishing guidelines for approval processes).

230. Norway Provisional Guidelines, supra note 212, at 2; Norway Amended Safety Regulations, supra note $211, \S 20$.

231. Norway Amended Safety Regulations, supra note 211, § 20.

232. Norway Provisional Guidelines, supra note 212, at 8-9.

233. Id. at 10 .

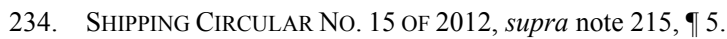


they are called upon to defend against a pirate attack, though they seem unwilling to opine on the laws of other states and the circumstances under which guards may find themselves criminally or civilly liable for using force that another state may deem excessive.

The guidance provided by the United States in this regard is illustrative. It allows ship personnel to use deadly force in self-defense or defense of others only when an individual has a "reasonable belief that the person or persons to which the deadly force would be directed poses an imminent danger of death or great bodily harm."235 Whether an imminent danger exists requires a fact-specific inquiry focusing on whether the attacker has the means and opportunity to do an act that may cause great bodily injury or death to others. Means and opportunity to perform a deadly act exist when an attacker has, or has apparent access to, a weapon that can be used against others and makes a movement that could cause another to believe the attacker is threatening great bodily harm-for example, pointing a weapon. ${ }^{236}$ More specifically, the guidance states that deadly force may be used when individuals without legal authority fire at, attempt to fire at, or attempt an armed boarding of a United States vessel carrying embarked individuals. $^{237}$ The guidance recognizes that the captain has command authority over the vessel and that any use of force "is subject to the direction of the vessel master."238 Before employing force, the ship's captain should consider all of the circumstances and resort to deadly force only where there is evidence of imminent danger of death or great bodily harm. $^{239}$

In the Coast Guard Authorization Act of 2010, the United States has also taken what appears to be the unique step among the states in this study of immunizing from liability for monetary damages those persons who defend a United States vessel against an act of maritime piracy while complying with the self-defense rules outlined above. ${ }^{240}$ At the same time, the Act makes clear that the United States can only immunize persons from liability under U.S. law-meaning that individuals could still face liability

235. PORT SECURITY ADVISORY 3-09, supra note 190, § 3(c).

236. Id. $\S 2(\mathrm{~d})$.

237. Id.

238. Id. $\S 3(\mathrm{c})$.

239. Id. $\S 3(\mathrm{a})$.

240. See Pub. L. No. 111-281, 124 Stat. 2905 (codified at 46 U.S.C. § 8107(a) (2012)) (stating that immunity shall apply to those who use force in accordance with the standard rules for the use of force in self-defense of vessels as prescribed by the Secretary of the Coast Guard). The prescribed standard rules are those outlined in the 2011 Guidance. See Self-Defense of Vessels of the United States, 76 Fed. Reg. 39,411 (July 6, 2011). 
for their conduct in other jurisdictions. ${ }^{241}$ It nevertheless states, in the text of the new Act, that the United States will work through the International Maritime Organization to persuade other states to enact limitations on liability similar to those established by the provisions of the Act. ${ }^{242}$

By its June 2012 Interim Guidance, the United Kingdom also provides some direction on what constitutes the appropriate level of force that may be used to defend against a pirate attack. In general, one could characterize the country's approach as a cautious one. The United Kingdom specifies that guards may use force, including lethal force, in self-defense or in defense of others as long as the amount of force used "is proportionate and reasonable in the circumstances as the defendant genuinely believed them to be."243 A guard need not wait for the aggressor to strike the first blow if the person believes that a threat of bodily harm is imminent. ${ }^{244}$ On the other hand, the Guidance explains that security teams should be seeking to disrupt any attempted boarding of the vessel "using the minimum force necessary." 245 In addition, any escalation in force should be graduated, and security personnel should not "needlessly escalate a situation."246 Indeed, the Guidance warns that any measures that show the ability to use force, such as making firearms visible or firing warning shots, should be carried out "so as not to be taken as acts of aggression." 247 As to using reasonable and proportionate force to prevent a crime more generally, the Guidance explains that piracy is a crime that can be defended against. ${ }^{248}$ It also notes, though, that the defense is only available to respond to crimes "in progress." 249

Like the United States' policy, the United Kingdom's policy recognizes the captain's command authority over the vessel and over any decision to use force. ${ }^{250}$ The Guidance states that the security team has to

241. See 46 U.S.C. $\$ 8107$ (a) (2012) (providing immunity to all ship crewmembers who use force in self-defense in U.S. waters).

242. Id. $\S 8107(\mathrm{~b})$.

243. JUNE 2012 INTERIM GUIDANCE, supra note 203, $\S \S 5.4,5.6$. The June 2012 Interim Guidance explains that in England and Wales, "whether a person used reasonable force will be assessed in the context of the circumstances as the accused genuinely believed them to be (even if he or she was mistaken as to the true circumstances)." Id. § 8.9 n.12.

244. Id. $\S 8.12$.

245. Id. $\S 8.3$.

246. Id. $\S 8.5$.

247. Id.

248. See id. $\S 8$ ("Defending against pirate attack").

249. Id. $\S 8.13$ ("If armed guards sighted a pirate skiff (i.e. a skiff obviously equipped to undertake acts of piracy), but there was nothing to indicate that the skiff was actively undertaking an act of piracy, it would be illegal for armed guards to use force against them.").

250. Id. $\S 5.1$. 
advise the captain of any responses available to counter any threat should the ship or crew be in danger of an attack. ${ }^{251}$ Thereafter, the captain "will be responsible for determining and exhausting all available options before recommending potential armed intervention to overcome a piracy threat." ${ }^{252}$ At the same time, the Guidance recognizes that there may be situations where the crew has "insufficient time" to seek the approval of the captain "before a course of action is taken." 253 In such cases, the security team must inform the captain about the course of action taken "as soon as possible afterwards and explain their reasoning for acting as they did.",254 In the event of an altercation with pirates, the United Kingdom advises that the captain and security team should both make detailed reports of any incidents to the relevant international institutions. ${ }^{255}$

Unlike the United States, the United Kingdom does not have a law specifically immunizing from civil monetary liability those who adhere to the legal standards regarding the lawful use of force in self-defense and defense of others in responding to pirate attacks. On the contrary, the Guidance explains that although having complied with "rules on the use of force may serve to reduce the risk of armed guards acting unlawfully," should criminal charges be brought, "[i]t would be for the enforcement agencies and then the court to decide whether the force used in the particular case was lawful." ${ }^{256}$ Moreover, the government offers no guidance on the laws of other countries, except to note that security personnel could be liable under laws of other jurisdictions for unlawful use of force depending, for example, on where the acts took place. ${ }^{257}$

Norway's guidance on the use of force by armed guards can also be described as cautious in approach. In Norway, the use of force by individuals - including private armed security guards - is limited to cases "of necessity or self-defence, i.e., cases in which there is no other way out and in which the requirements of necessity, reasonableness and proportionality are observed in connection with the use of force." ${ }^{\text {,25 }}$ But the guidance advises that the use of force should be avoided whenever possible; should only be employed after other, less radical measures have been attempted; and should only be used against a threat that is "direct,

251. Id. $\S 5.4$.

252. Id.

253. Id. $\$ 5.5$.

254. Id.

255. Id. $\$ 9.1$.

256. Id. $\S 8.6$.

257. Id. $\S 8.8$.

258. Norway Provisional Guidelines, supra note 212, at 2. 
immediate, significant and otherwise unavoidable." 259 Further, firing shots at a person to render him harmless may only occur after other, gentler means have been employed or where no alternative has any chance of success. ${ }^{260}$

In Norway, the decision of whether to authorize the use of force rests with the ship's captain. ${ }^{261}$ Any use of firearms must be approved by the captain in each individual case and, if circumstances permit, only after attackers are warned by means of light and sound signals and warning shots. $^{262}$ While any such use of force must be "proportionate in view of the scope of the threat and the conditions otherwise," 263 the guidance notes that the captain has significant discretion "when faced with an unclear and apparently precarious situation." 264 In fact, even when pirate vessels are 2,000 meters away, the captain may reasonably conclude that a pirate attack is immediate and may require the use of force to repel. ${ }^{265}$ The captain is also charged with the task of having to report to the appropriate government entity any use of firearms to repel a pirate attack, including that which results in injury or death. ${ }^{266}$

Persons employing force will only be immune from criminal prosecution under Norwegian law if the use of force is not excessive. ${ }^{267}$ Because individuals must in every case independently determine whether their use of a firearm is lawful, individuals may be criminally liable for excessive use of force even if acting in accordance with the captain's authorization. Because the ship owner and the captain are responsible for establishing conditions under which force may be used, in some cases both may also be liable in the event an individual marksman's use of force is excessive. $^{268}$ On the other hand, if the marksman acts contrary to the captain's instructions, the marksman will likely be the only subject of any

259. Norway Provisional Guidelines, supra note 212, at 12; Norway Amended Safety Regulations, supra note $211, \S 17(2)$.

260. Norway Provisional Guidelines, supra note 212, at 13; Norway Amended Safety Regulations, supra note $211, \S 24(4)$.

261. Norway Amended Safety Regulations, supra note 211, § 17(1).

262. Norway Provisional Guidelines, supra note 212, at 12-13; Norway Amended Safety Regulations, supra note 211, $\S \S 24(1), 24(3)$. On the other hand, the ship's captain need not specifically approve each use of firearms and may instead rely on standing orders in some cases, such as in the case of a night watch. Norway Provisional Guidelines, supra note 212, at 12.

263. Norway Provisional Guidelines, supra note 212, at 12; Norway Amended Safety Regulations, supra note $211, \S 17(2)$.

264. Norway Provisional Guidelines, supra note 212, at 12.

265. Id.

266. Id. at $13-14$.

267. Id. at 5 .

268. Id. at 6 . 
criminal prosecution. ${ }^{269}$ In some special cases, criminal liability may even attach to the security firm from which any guard using excessive force was hired. $^{270}$

Neither Denmark nor Singapore provides any specific guidance on the appropriate level of force that guards may use to repel pirate attacks. Denmark does refer ship owners to the various IMO Circulars on the use of private armed security guards. ${ }^{271}$ Singapore's Shipping Circular notes that while the crew and any private security personnel may lawfully bear arms, "they will still be liable under Singapore's laws if they use their arms on board the ship without lawful excuse, as a person on board is not exempted from criminal liability in respect of any offence that he commits on the ship.,272 Otherwise, the Circular refers ship owners to the remaining guidance contained in the IMO's Circular, which, it notes, contains advice on the command relationship between the captain and any security team, the rules regarding the use of force, the management of arms and ammunition, and the need for proper recordkeeping. ${ }^{273}$

\section{Laws and Guidance on Weapons Carriage}

Using private armed guards also poses risks associated with weapons carriage and transport. The need to comply with various state laws can be a burden but has also created a situation in which PMSCs are stocking floating armories on the high seas - a situation which could create significant problems if those arms are not properly safeguarded. ${ }^{274}$ Again, however, the comparison of state laws and guidance shows that states are taking different approaches to dealing with the potential issues relating to weapons carriage and transport. Moreover, the comparison suggests that states could regulate much more comprehensively than they are: their guidance, for example, does not address floating armories or the fact that guards can rent any number of automatic weapons in foreign ports.

In the United States, for instance, ship owners and guards must comply with U.S. weapons laws, as well as with any applicable port state laws regarding weapons carriage. Most particularly, they must comply with the International Traffic in Arms Regulations (ITAR), which require individuals and corporations of the United States to obtain a license in

269. Id. at 13 .

270. Id. at 6 .

271. DANISH STRATEGY, supra note 205, at 27.

272. ShipPING CirCUlaR No. 15 OF 2012, supra note 215 , 93.

273. Id. $₫ 2$.

274. See discussion supra Part II.B. 
order to export or import, among other things, firearms and ammunition. ${ }^{275}$ The terms "exporting" and "importing" include any manner of "sending or taking" the prohibited articles out of the United States. ${ }^{276}$ Under some circumstances, individuals may qualify for an exemption from ITAR's licensing requirement, but in that case they will only be allowed to export up to three non-automatic firearms and 1,000 rounds of ammunition. ${ }^{277}$

According to a Port Security Advisory issued in 2010, United States vessel operators may apply for a temporary export license under ITAR should they decide to board firearms. ${ }^{278}$ Such licenses are valid for up to four years and may be used for multiple trips to and from the United States. $^{279}$ To obtain a temporary license, the ship owner must identify the precise firearms and ammunition that would be carried on board the vessel and must also list the foreign countries for each port of call the ship will visit during that time period. ${ }^{280}$ While the temporary license would allow the ship owner to alter the personnel travelling on the vessel, it would not allow the firearms to be transferred to any other vessel. ${ }^{281}$ The Advisory explains that to be eligible for a temporary license under ITAR, the arms must be for the individual applicant's exclusive personal use. ${ }^{282}$ In addition, because the exemption only applies to individuals, it cannot be used by companies that "desire to hire security teams that will not travel with their weapons or where weapons will be transferred from one security team or crew member to another."283 In such circumstances, the vessel owner should obtain a temporary license to cover the vessel's carriage of weaponry. $^{284}$

The Advisory also notes that United States law places other restrictions on the use of firearms, such as registration and transfer approval requirements, with which vessel owners and individuals must

275. See generally 22 C.F.R. $\S ~ 120-30$ (2013); see also 22 C.F.R. $§ 121.1$ (listing firearms and ammunition as among the articles covered by the ITAR). The ITAR were issued by the Secretary of State pursuant to authority granted by the President pursuant to Executive Order 11958. Exec. Order No. 11,958, 42 Fed. Reg. 4,311 (Jan. 18, 1977). Section 38 of the Arms Export Control Act, 22 U.S.C. $\S 2778$ (2012), authorizes the President to control the export and import of defense articles. PLOCH 2011, supra note 31 , at 38 .

276. 22 C.F.R. $\S 120.17$ (a) (2013).

277. 22 C.F.R. $\S 128.18(\mathrm{c})(2013)$.

278. U.S. CoAst Guard, DeP'T OF Homeland SeC., Port Security Advisory (4-09) (ReV 4): INTERNATIONAL TRAFFIC IN ARMS REGULATIONS (ITAR) 1 (Sept. 3, 2010).

279. Id.

280. Id. at $1-2$.

281. Id. at 2 .

282. Id.

283. Id.

284. Id. 
comply. ${ }^{285}$ It also emphasizes that vessel owners and operators, as well as PMSCs, must comply with any weapons carriage or transport laws of foreign states in whose ports they call or through whose waters they pass. $^{286}$ On the other hand, vessel owners and individuals may avoid ITAR licensing requirements should they purchase weapons in a foreign country and stow them while in a foreign port (assuming doing so does not violate the laws of the applicable foreign country). ${ }^{287}$ Should they seek to bring those weapons back into the United States, however, they would have to abide by United States weapons importation laws. ${ }^{288}$

Like the United States, the United Kingdom also regulates the carriage and transport of weapons by armed guards. ${ }^{289}$ The June 2012 Interim Guidance explains that only members of the security team are permitted to handle firearms on board UK flagged ships and that no person may possess a prohibited firearm without obtaining the proper licenses. ${ }^{290}$ The government and its police will conduct background checks on the PMSC and its personnel before granting any license to carry "prohibited firearms" on British ships. ${ }^{291}$ Laws also govern removing firearms or ammunition from the country. ${ }^{292}$ Thus, British companies seeking to provide armed guards on ships must now obtain a special export license-called an Open General Trade Control License-from the country's Export Control Organisation (ECO). ${ }^{293}$ The Open General Trade Control License permits security firms to deliver or transfer arms and ammunition through foreign territories. $^{294}$ To obtain the license, the PMSC must, among other things, submit to the government copies of its rules of engagement and its policies

285. Id. at 3 .

286. Id. at 4 .

287. Id. at 3 .

288. Id.

289. It bears noting that England and Wales generally have very strict gun laws and that even the police do not carry firearms. Jon Kelly, Why British Police Don't Have Guns, BBC News Magazine, BBC.COM (2012), http://www.bbc.co.uk/news/magazine-19641398. Individuals may only possess arms if they complete and comply with a rigorous licensing process, and possession of a firearm without a license is a criminal offense. Firearms Act, 1968, c. 27, § 5, available at http://www.legislation.gov.uk/ ukpga/1968/27; Firearms Licensing: Frequently Asked Questions, METROPOLITAN POLICE, http://www .met.police.uk/firearms_licensing/faqs.html (last visited Sept. 24, 2013).

290. JUNE 2012 INTERIM GUIDANCE, supra note 203, § 6.5 .

291. THORP, supra note 121 , at 11.

292. JUNE 2012 INTERIM GUIDANCE, supra note 203, $§ 6.15$.

293. Id. $\S 6.16$. For details about the Open General Trade Control License, see Open General Trade Control Licences, Department for Business Innovation \& Skills, Gov.UK (Dec. 12, 2012), https:// www.gov.uk/open-general-trade-control-licences.

294. Trade Licence: Open General Trade Control Licence (Maritime Anti-Piracy), Department for Business, Innovation \& Skills, Gov.UK (Feb. 22, 2012), http://www.bis.gov.uk/assets/biscore/eco/ogelscurrent/12-628-ogtcl-maritime-anti-piracy.pdf. 
on safely storing firearms. ${ }^{295}$ It must also maintain records showing proper usage of the license. ${ }^{296}$ Failure to comply with licensing requirements can result in withdrawal of the license or possibly even prosecution. ${ }^{297}$

The Guidance anticipates that British ship owners and operators will not ordinarily need to export any firearms or ammunition from the United Kingdom. ${ }^{298}$ Rather, since ship owners may only employ armed security personnel in high risk areas, the expectation is that the security team and their arms and ammunition will likely embark and disembark outside the territory. ${ }^{299}$ Nevertheless, British ship owners still need to comply with the weapons carriage and usage laws of the coastal states through which they travel or be subject to liability for failing to do so in those foreign jurisdictions. $^{300}$

Norway also regulates the use of weapons, including by private security personnel. Individuals must obtain a permit from the chief of police in order to own or hold firearms on Norwegian soil, including on its flagged ships. ${ }^{301}$ Norwegian flagged ship owners wanting to bring armed guards on board their ships are also required to obtain a general firearms permit allowing them to hold prohibited weapons on board. ${ }^{302}$ Such permits are valid for up to six months and are not linked to individual firearms or a specific assignment or security firm. ${ }^{303}$ Instead, the licenses will more generally allow the ship owner to hold otherwise prohibited weapons, including fully automatic guns or single-shot repeating weapons. ${ }^{304}$ To comply with the license, the ship owner must submit to the government - and follow - a plan to safely store and transport firearms and ammunition in a manner that will keep unauthorized persons from gaining access to them. ${ }^{305}$ Norway's Provisional Guidelines further caution the ship owner to ensure that it can comply with any relevant port laws where its guards will embark or disembark. ${ }^{306}$

Lastly, Denmark provides little express guidance on arms carriage other than in its requirements for the arms certificate for which ship owners

295. Id.

296. Id.

297. Id.

298. JUNE 2012 INTERIM GUIDANCE, supra note 203, § 6.12 .

299. Id.

300. Id. $\S \S 6.8-6.11$.

301. Norway Provisional Guidelines, supra note 212, at 3.

302. Id. at 6 .

303. Id.

304. Id. at 7.

305. Id. at 11 .

306. Id. at 9 . 
must apply in order to employ armed guards. In that regard, Denmark makes ship owners identify the specific weapons the ship seeks to bring on board, the methods for storing those weapons, and whether the arms will be carried out of or into Denmark. ${ }^{307}$ Likewise, Singapore has not issued specific guidance on arms carriage except to refer ship owners to the various IMO Circulars on the use of private armed security guards. ${ }^{308}$

\section{A CALL FOR MORE COORDINATED REGULATION}

As the comparison of state laws and guidance shows, states have taken various approaches towards regulating the use of private armed guards in the fight against maritime piracy. Still, even more needs to be done. States that have not issued any precise guidance regulating the selection of armed guards or advising them on the lawful use and transport of weapons should do so. States that have issued guidance in these respects should be more precise. More importantly, this Article urges states to work together and arrive at one set of clear regulations to govern the use and conduct of private armed guards in the maritime piracy context. Maritime piracy is an international crime, and the fight against it occurs on international waters. Moreover, states are responsible for the fight against piracy. Thus, all states should ensure that the private contractors that they allow to use guns to protect ships against piracy act lawfully and properly when doing so.

The best way to establish one clear set of regulations governing the use and conduct of armed guards is through an international convention. By that convention, states could agree on the necessary qualifications for any maritime security personnel. They could also agree on the types of weapons that guards may use, the circumstances under which they may use them, and the methods by which they may store and transport them.

Even without an international convention, states could do a better job of mitigating the risks associated with using private armed guards. To that end, the sections that follow suggest some standards or practices that all states should adopt or on which they should agree to help minimize the risks and practical difficulties associated with employing these private actors. Deterrence of pirate attacks by armed guards benefits the world community. That benefit may be outweighed, however, unless states work together to ensure that the use of armed guards does not unnecessarily escalate violence, involve the unlawful use of force, endanger innocent

307. Information ThAT SHOULd ACCOMPANY A SHIPPING COMPANY's APPLICATION FOR USING ARMED CIVILIAN GUARDS ON BOARD DANISH SHIPS, supra note 227.

308. See ShIPPING CirCUlAR No. 15 OF 2012, supra note 215 ("This circular serves to inform on the revised interim guidance being promulgated by IMO in the document MSC.1/Circ. 1405/Rev.2 ...."). 
seafarers, or cause international incidents.

\section{A. The Regulation and Monitoring of the PMSC Industry Generally}

As an initial matter, states should work together to make certain that the PMSC industry is regulated and monitored so that only properly vetted personnel can protect commercial vessels travelling through pirate-infested waters. Allowing private armed guards to supplement the work of United Nations-sanctioned naval patrols carries the risks that private guards may be woefully undertrained as compared to their government military counterparts and also that they may not be subject to the same monitoring mechanisms. If states are not actually regulating and monitoring PMSC conduct, the risk that untrained "cowboy" guards will be patrolling the seas is a real one.

The comparison of state laws, however, suggests that for the most part, states do not want to play a role in regulating the PMSC industry or vetting guards. This is not to suggest that states have not made a helpful contribution by issuing some guidelines that ship owners should follow when conducting due diligence of the various PMSCs they might seek to hire. Providing non-binding guidance, however, is not the same as subjecting PMSCs to some form of regulation that includes accreditation standards and monitoring to ensure that those standards are followed. Giving ship owners a list of items to address when conducting due diligence does not necessarily ensure that the ship owner will ferret out a PMSC that is disreputable or whose guards are not properly trained. Ship owners are not necessarily experts in the maritime security industry and will likely rely on the PMSCs' own marketing materials and statements when choosing a firm. Further, ship owners face the competing incentive of wanting to employ a less costly PMSC, even if it means that the guards they hire do not have the highest level of qualifications. The fact that some states also require ship owners to provide the state with information about the PMSC and its guards is an exercise that should help impress upon ship owners the need to hire a reputable firm. That advance information about the PMSCs may also be helpful should the state, or others, need to investigate any later claim that a guard used unlawful force. Unless PMSCs are more meaningfully vetted by some entity with appropriate expertise, ship owners may still wittingly, or unwittingly, hire armed guards who are not well trained or not prepared to abide by all applicable laws governing the carriage and use of weapons.

Rather than passing the buck to ship owners, states need to accept responsibility for ensuring that only qualified, trained, and responsible security personnel play a role in the fight against maritime piracy. Indeed, 
states bear the overall responsibility to undertake that fight. ${ }^{309}$ State regulation of PMSC licensing or accreditation standards and monitoring mechanisms to ensure compliance would provide a needed level of protection against the possibility of untrained guards operating on the high seas. ${ }^{310}$ Nevertheless, for any such PMSC regulatory scheme to be optimal, states cannot operate in isolation. All states should agree on a set of standards; otherwise, substandard PMSCs will find states with looser standards on whose ships their guards can operate. Absent an agreed-upon international standard, PMSCs will be able to register themselves in a different jurisdiction so as to take advantage of lax laws. These very issues have been raised in the more general context of private military security services. In that context, commentators have noted that unless all states agree on a regulatory system, firms will simply move their operations to a "more hospitable" country where laws will allow them to operate with little or no oversight. ${ }^{311}$

Although getting all states to agree on a regulatory scheme for PMSCs may require some effort, the payoff is safer seas for all who travel through them - a payoff that all states should want to realize. Nor would states need to start with a blank slate in creating such a regulatory scheme. Indeed, the maritime industry is undertaking various steps to encourage PMSCs to engage in self-regulation. In late 2012, the International Organization for Standardization (ISO) issued guidelines setting out some best practices that PMSCs should adopt to ensure their companies and personnel offer quality, professional services to ship owners seeking antipiracy protection. ${ }^{312}$ In addition, one non-governmental organization, the Security Association for the Maritime Industry (SAMI), has begun work on

309. Most states, in fact, are parties to UNCLOS and have pledged to "cooperate to the fullest extent possible in the repression of piracy." UNCLOS, supra note 5, art. 100. For a list of state ratifications, see Div. for Ocean Affairs and the Law of the Sea, Office of Legal Affairs, Chronological Lists of Ratifications of, Accessions and Successions to the Convention and the Related Agreements as at 29 October 2013, UNITED NATIONS (Oct. 29, 2013), http://www.un.org/depts/los/reference_files/ chronological_lists_of_ratifications.htm.

310. States like the Netherlands could continue to allow their ship owners to only hire VPDs. VPDs are comprised of government military personnel who presumably would meet any training standards agreed upon for PMSCs. See discussion supra Part II.A. Indeed, one reason ship owners have urged states to provide them with military armed guards is because of the presumption that on the whole most military personnel are properly trained and prepared to abide by applicable laws. Id.

311. Deven R. Desai, Have Your Cake and Eat It Too: A Proposal For a Layered Approach to Regulating Private Military Companies, 39 U.S.F. L. REV. 825, 851 (2005).

312. International Organization for Standardization [ISO], Ships and Marine Technology Guidelines for Private Maritime Security Companies (PMSC) Providing Privately Contracted Armed Security Personnel (PCASP) on board Ships (and Pro Forma Contract), ISO/PAS 28007:2012 (2012) [hereinafter ISO Guidelines] (on file with the Duke Journal of Comparative and International Law). 
an accreditation system for PMSCs. ${ }^{313}$ Headquartered in the United Kingdom, SAMI's stated aim is to "facilitate clear dialogue and a common standards framework in the delivery of maritime security products to the shipping community." 314 PMSCs that join SAMI for a fee may also choose to participate in its recently-introduced Certification Program. Participants in that program submit to an independent auditing process so as to be recognized as an accredited and reputable security provider. ${ }^{315}$ That auditing process involves a review of company documentation and an onsite visit whereby SAMI experts examine management and operational logistics, including the management of personnel. ${ }^{316}$ As of early January 2013, approximately 30 PMSCs had successfully passed the documentation phase of SAMI's certification process. ${ }^{317}$ Recent reports, in fact, indicate that SAMI will be overseeing a similar certification process for PMSCs that want to demonstrate compliance with the new ISO Guidelines. ${ }^{318}$

The ISO Guidelines and the SAMI and ISO certification processes are certainly a welcome step in regulating the PMSC industry. But these standards and processes are voluntary: the professional PMSCs will likely embrace them to demonstrate their quality and capabilities. Without a state-required, mandatory system with oversight and penalties for noncompliance, what assurances are there that all PMSCs operating on the high seas will conduct themselves according to these high standards? Selfregulation is no substitute for uniform and coordinated state regulation.

Nevertheless, states could build on these self-regulation efforts and establish a similar certification process for PMSCs. If states investigated the current certification processes and concluded that they were sufficiently rigorous, they might be able to agree on a regulatory scheme that allows ship owners to only hire, for example, SAMI-certified PMSCs. Initial certification should not constitute the end of the process, however. To make certain that PMSCs continue to deliver quality, reputable services, they would need to be monitored by way of a public reporting mechanism

313. Id.

314. SEC. ASS'N FOR THE MAR. INDUS., GUIDELINES ON JOINING THE SECURITY ASSOCIATION FOR THE MARITIME INDUSTRY (2012), available at http://www.seasecurity.org/wp-content/uploads/SAMIJoining-Guide-Dec-2012.pdf.

315. SAMI Certification for PMSCs, SECURITY ASS'N FOR MAR. INDUSTRY, http://www. seasecurity.org/sami-certification-for-pmscs/ (last visited Sept. 6, 2013).

316. Id.

317. Certified Members, SECURITY ASS'N FOR MAR. INDUSTRY, http://www.seasecurity.org/ certified-members/ (last visited Sept. 6, 2013).

318. Gavin van Marle, New Anti-Piracy Standards Will Boost Confidence in Private Guards, LOADSTAR (June 19, 2013), http://theloadstar.co.uk/new-anti-piracy-standards-will-boost-confidencein-private-guards/. 
or some external audit procedures. Here again, states could place such a monitoring function in the hands of an institution like SAMI. ${ }^{319}$ To defer the costs of certification and monitoring, states could implement a feebased system, much like that used by SAMI for its members. ${ }^{320}$ In any event, states are already spending billions on the navies that patrol on antipiracy missions. $^{321}$ If they have to contribute additional sums to ensure that the supplemental private forces they permit ship owners to hire are qualified and trained to properly and lawfully use and transport weapons, that money will be well spent.

\section{B. Use of Force}

Coordinated regulation and monitoring of the PMSC industry should help to ensure that guards are properly trained on the lawful use of force. States, however, should work together on coordinated guidance specifically addressing when guards may properly use lethal force. If states do not articulate clear rules on the use of force, or even if those rules differ among states, guards may have difficulty knowing what is expected of them. In this international context, guards may be employed by a PMSC that operates in one state, they may be hired by a shipping company flagged in a different state, and they may find themselves repelling an attack against still another state's nationals or in another state's territory. The analysis of state laws above demonstrates the need for all states to provide clear and concrete guidance on the use of force and to increase the level of uniformity in that guidance where possible. Recall that Denmark and

319. For a detailed discussion of how one might structure an international framework to regulate the private military security companies that contract with governments to supplement and help support armed forces participating in various armed conflicts and in post-conflict peacekeeping operations, see Peter W. Singer, War, Profits, and the Vacuum of Law: Privatized Military Firms and International Law, 42 COLUM. J. TRANSNAT'L L. 521, 544-46 (2004).

320. Some evidence indicates that the United Kingdom is working with a trade industry partner, the Security in Complex Environments Group (SCEG), to establish a regulatory framework to govern its PMSCs. According to the SCEG website, the approach currently under consideration would involve a mixture of self-regulation and external audit. See About the SCEG, SECURITY IN COMPLEX ENV'TS GROUP (June 12, 2013), http://www.adsgroup.org.uk/pages/19813174.asp. Germany also seems to be in the process of amending its laws to require PMSCs to meet certain licensing requirements before they can be hired to work on German flagged ships. Gesetzentwurf der Bundesregierung: Entwurf eines Gesetzes zur Einführung eines Zulassungsverfahrens für Bewachungsunternehmen auf Seeschiffen [Draft Law to Establish a Procedure for Security Companies on Seagoing Vessels], Oct. 10, 2012, at 17, 10960, amending HANDELSGESETZBUCH [HGB] [Commercial Code], Feb. 22, 1999, [BGBL. I] 202, as amended. According to the proposed laws, a federal agency will be tasked with administering the licensing process, determining whether requirements for licensing are made, id. at 7-10, and for publishing a list of approved companies, $i d$. at 14. Both the United Kingdom and German frameworks could also serve as guides for a framework to be adopted by all states to regulate PMSCs.

321. See supra note 67 and accompanying text. 
Singapore authorize the use of armed guards but that they do not provide any details on when guards may use lethal force to repel a pirate attack. ${ }^{322}$ Both countries presumably have general self-defense laws that PMSCs could independently research. This approach, though, leaves significant room for error. States are responsible for the fight against piracy, and they are also in the best position to articulate the precise contours of their laws. Leaving it to PMSCs to decipher state laws on the use of force may save the state some time at the outset, but it will not guarantee that state laws are followed or that international incidents are avoided.

Lack of uniformity among state laws on the use of force may also cause confusion since guards may be required to interpret and comply with different sets of laws and guidance. The United States and the United Kingdom authorize deadly force where guards possess a reasonable belief that lives are in imminent danger. ${ }^{323}$ Norway's laws seem similar in permitting deadly force in response to a threat that is "direct, immediate, significant and otherwise unavoidable." ${ }^{324}$ Nevertheless, there are reasons to suspect these states may not necessarily reach the same conclusion about whether the use of force in any given instance was lawful. For example, Norway only allows firing shots to render a person harmless after employing more gentle means or where no alternative has any chance of success. ${ }^{325}$ At the same time, its guidance provides that a pirate attack may be immediate and that force may be used to repel an attack even if pirate vessels are 2,000 meters away. ${ }^{326}$ The guidance issued by the United Kingdom states that guards must "use the minimum force necessary" to disrupt any attempted boarding of the vessel and that as long as there is nothing to indicate a pirate skiff is actively undertaking an act of piracy, guards would be wrong to use force against them. ${ }^{327}$ Can the guidance of both states be reconciled? Would the actions of the guards on the Avocet be legal under either set of guidelines? Under Norway's or the United Kingdom's guidance, do the guards need to see the alleged pirates aiming weapons before they are permitted to use lethal force in self-defense?

States need to clarify not only what level of force may be used under

322. See supra notes $271-73$ and accompanying text.

323. See JUNE 2012 INTERIM GUIDANCE, supra note 203, $\mathbf{q}$ 8.9, 8.10, 8.12 (stating that the United Kingdom allows deadly force to defend against imminent danger to lives as long as the force is "proportionate and reasonable in the circumstances as the defendant genuinely believed them to be."); PORT SECURITY ADVISORY 3-09, supra note 190, § 4(d) (stating that the United States permits deadly force when an individual has a "reasonable belief" of imminent danger to lives).

324. See supra note 259 and accompanying text.

325. See supra note 260 and accompanying text.

326. See supra note 265 and accompanying text.

327. See supra notes 245,249 and accompanying text. 
certain circumstances but also other matters relating to the use of force: who may authorize the use of force, whether and to whom notice should be given if force is used, and whether and to whom liability might attach if excessive force is used. State guidance must also be sufficiently detailed so that guards actually know what is expected of them. To simply indicate that the captain is in control of the vessel and must authorize any use of force can leave room for interpretation-and for errors. Yet, this is essentially the guidance provided by the United States. ${ }^{328}$ By contrast, the more specific guidance of the United Kingdom indicates that the security team must advise the captain of available responses to counter any threat and that the security team may only take action after obtaining the captain's approval-or, if exigent circumstances did not permit an advance discussion, must discuss any use of force with the captain afterwards. ${ }^{329}$

Here, again, the maritime industry has made some efforts at selfregulation. Attached to the new ISO Guidelines is a recommended standard contract to be used by ship owners when employing armed guards. $^{330}$ The contract, developed by the shipping industry organization BIMCO in 2012, addresses the need for private guards to abide by laws regulating the use of force. ${ }^{331}$ These are admirable efforts, and some ship owners likely do require their guards to sign such a contract and also caution the guards to only use lawful force. As with vetting and accreditation, however, unless states agree on some rules of force and make those clear to guards, there are no assurances that guards can, or will be able to, abide by them. By failing to provide guards with detailed guidance, and by not coordinating that guidance, states are running the risk that guards do not know what is expected of them or that another state disagrees with a guard's use of force.

Further, the notice provisions of the United States, the United Kingdom, and Norway are different. Norway requires notice to its government when force is used to repel an attack. ${ }^{332}$ The United Kingdom advises that the captain and security team should make detailed reports of any incidents to certain relevant international institutions. ${ }^{333}$ This seems an

328. See supra note 238 and accompanying text.

329. See supra notes 251-54 and accompanying text.

330. ISO Guidelines, supra note 312.

331. Id.; see also The Baltic AND InT'L MAR. Council, GuARdCON-CONTRACt For the

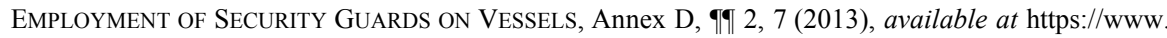
bimco.org/Chartering/Documents/Security/ /media/Chartering/Document_Samples/Sundry_Other_For ms/Sample_Copy_GUARDCON_04_01_2013.ashx.

332. See supra note 266 and accompanying text.

333. See supra note 255 and accompanying text. 
area where states should agree that broad notice is required following an incident since the fight against maritime piracy occurs in the international arena and the international community has an interest in ensuring that any use of force was appropriate.

Finally, the issue of liability is not only one on which states should provide information to their constituencies but is also one on which they should cooperate to reach some agreements about jurisdictional priorities in case questions arise about whether any guards used excessive force. It is well settled that private citizens must comply with the laws of any state in whose territory they appear or risk civil or criminal liability in that foreign jurisdiction. ${ }^{334}$ Thus, as the United Kingdom has warned, PMSC personnel may find that, in addition to the United Kingdom, "other countries may also have a right to assert jurisdiction over a case and apply their own nationals laws governing the use of force"-depending, for example, on where the offense occurred or the nationality of the victims or perpetrators. ${ }^{335}$ What, though, are the rules for state military personnel who have been hired out by the state as part of a VPD? As the Enrica Lexie incident demonstrates, not all states will necessarily agree that military personnel hired to work in a private capacity are entitled to any of the same immunities that might be granted to military personnel working on state military missions. ${ }^{336}$ The only way to avoid additional, similar diplomatic disagreements about whether immunity applies is for states to agree on clear rules in advance. States have negotiated Status of Forces Agreements for their military personnel. ${ }^{337}$ They can take the same or similar precautions if they want to use and obtain immunity for their VPD military personnel.

Even if states do not reach any such agreements, they should still seek to agree on a process for determining which state will be able to exercise jurisdiction if the use of force results in injury or death. This may not be easy to accomplish since states will have to agree to surrender jurisdiction even before they know the precise factual circumstances of an event. But why could they not agree to allow the flag state to exercise primary jurisdiction over offenses committed by private guards acting on antipiracy missions as long as the flag state had procedures for vetting guards and laws to punish for excessive force? With these provisos, the foreign jurisdiction should have some assurances that the guards were not

334. See supra note 145 and accompanying text.

335. JUNE 2012 INTERIM GUIDANCE, supra note 203, $§ 8.8$.

336. See supra notes $146-50$ and accompanying text.

337. See supra notes $143-45$ and accompanying text. 
untrained "cowboy" guards. The requirement that the flag state have laws to punish excessive force should provide some assurances that justice will be done - though it will not eliminate the risk that the flag state fact finder may reach a different conclusion as to whether force was excessive under the circumstances. Indeed, such a regime would not be unlike that which states negotiate when they enter into SOFAs.

It may not be realistic to expect that states will amend their criminal codes so that they all have identical rules on when civilians may use force in self-defense or defense of others. This does not mean that states permitting private armed guards on their ships cannot provide clear and detailed guidance on what is expected of those guards. It also does not mean that states cannot agree on uniform rules that govern aspects of the use of force that are unique to the maritime piracy context, such as command authority and notice provisions. States can also minimize the potential for diplomatic tensions if they agree in advance on how they will resolve jurisdictional disputes should guards use force in a situation where laws in addition to those of the flag state could apply. The need to avoid chaos on the high seas is good reason for states to provide clear, detailed, and uniform guidance.

\section{Weapons Carriage}

Lastly, it is imperative that states work together to develop clear and concrete rules regarding weapons carriage. Flag states can take the lead by strictly regulating weapons carriage, including the types of weapons guards can use and how they can obtain them. Yet, as the comparison of state laws and guidance shows, not all states specifically regulate weapons carriage and some regulations have significant and important gaps in their coverage. Both the United States and the United Kingdom require special licenses for the export of firearms. ${ }^{338}$ But the U.S. guidance also explains that U.S. export laws may not apply when private guards obtain weapons in foreign ports and do not bring them back to the flag state. ${ }^{339}$ Thus, even the United States' regulatory scheme seemingly permits guards to buy or lease firearms, including automatic weapons, while in some foreign port states. The United States' laws and those of other states also do not seem to specifically prohibit guards from obtaining weapons from the many floating armories operating on the high seas. ${ }^{340}$ Yet, without such a

338. See supra notes $275-300$ and accompanying text.

339. See supra notes $287-88$ and accompanying text.

340. For a discussion of the practice of using floating armories, see supra notes 97-98, 125-35 and accompanying text. 
specific prohibition, states have lost an opportunity to monitor weapons access, thus potentially putting innocent lives at risk. Additionally, if floating armories are not well guarded, they could be accessed for criminal purposes. At present, however, no national or international regulations govern the use of floating armories. ${ }^{341}$

Fully regulating weapons carriage will require flag states to decide whether the guards that their ship owners hire should be allowed access to particular types of weapons, such as fully automatic firearms. If the state concludes that access to such weapons unnecessarily increases the possibility that guards will violate laws on the use of force, then the state should ensure that its regulations permit it to exercise some oversight. In this regard, Denmark appears to have a helpful model on which states might build since it requires its ship owners to identify the specific weapons that will be brought on board before the ship owner may obtain a firearms certificate. ${ }^{342}$ Even Denmark's regulations, however, could be more specific by providing that the ship owners and guards are prohibited from obtaining those weapons from a floating armory.

The existence of the new and unregulated floating armories raises an additional issue: different port states have different laws regulating the carriage and transport of weapons. After all, PMSCs apparently developed the practice of using floating armories to avoid navigating what some have suggested is a complicated legal minefield. ${ }^{343}$ An agreement among all port states to permit armed security personnel to carry certain weapons in their territory for the limited purpose of participating in a sanctioned antipiracy mission would help to eliminate the difficulties of following different port state laws. Some evidence already indicates that port states are willing to cooperate in this regard. Even though Singapore has strict weapons laws, the Netherlands has apparently reached an agreement with it to allow the storage of weapons and ammunition in Singapore's port for use by its VPDs. ${ }^{344}$ As of late 2011, Egypt had banned commercial ships from carrying any weapons in its ports, but by early 2012, it had changed its laws to allow foreign weapons in its territory as long as the weapons were kept in a sealed container and delivered to Egyptian authorities while the ship was in port or travelling through the Suez Canal. ${ }^{345}$ Other port

341. See supra note 130 and accompanying text.

342. See supra note 228 and accompanying text.

343. See supra note 97 and accompanying text.

344. See supra note 135 and accompanying text.

345. In late 2011, Egypt decreed that commercial ships travelling through its waters were prohibited from carrying weapons on board; violations would be punished by arrest of the ship, the captain, and any armed personnel. Egypt Bans Weapons on Ships Transiting Its Waters, BANGKOK 
states may also be persuaded to change their laws to allow for weapons carriage - particularly if the international community actually agrees to regulate and vet PMSCs so that only trained and reputable guards would be participating in the fight against piracy.

Alternatively, if port states cannot be persuaded to allow security personnel to carry certain weapons in their territories under certain circumstances, states need to ensure that ship owners and PMSCs fully understand and comply with the various port state laws regarding weapons carriage. States should not be able to simply issue general warnings on the need to comply with laws of foreign states through which the vessel passes. $^{346}$ It may be difficult for states to obtain information about different state laws, especially if those laws are sometimes in flux, as they may be given that the use of armed guards conducting anti-piracy missions is a relatively new phenomenon. ${ }^{347}$ On the other hand, the IMO has identified areas that pose the greatest risk of pirate attacks, ${ }^{348}$ and some states, like the United Kingdom, will only permit armed guards to operate on their flagged ships in those identified high risk areas. ${ }^{349}$ States authorizing the use of armed guards could at least take the initiative to provide their constituencies with information about the weapons carriage laws of the limited number of states bordering the areas posing the highest threat of pirate attacks. ${ }^{350}$ Again, states are charged with fighting maritime piracy, and they should take the lead in ensuring that the fight is carried out safely and in compliance with all relevant laws, rather than in a way that might encourage guards to rely on floating armories on the high seas.

SHIPOWNERS AND AGENTS ASS'N (Sept. 16, 2011, 12:24), http://www.thaibsaa.com/news/worldshipping-news/362-egypt-bans-weapons-on-ships-transiting-its-waters.html. In early 2012, Egypt changed its laws to require vessels to file a declaration 48 hours before arriving at an Egyptian port or transiting through the Suez Canal with details regarding any weapons, ammunition, and guards on board, as well as confirmation that weapons and ammunition will be in a sealed box for delivery to Egyptian authorities until the ship leaves port or exits the Suez Canal. Egypt-Carriage of Weapons, Ammunition, and Armed Guards - Further Update, WEST OF ENG. (Feb. 22, 2012), http://www. westpandi.com/Publications/News/Archive/Egypt--Carriage-of-Weapons-Ammunition-and-ArmedGuards-Update/.

346. See, e.g., supra note 300 and accompanying text (discussing the United Kingdom guidance warning states of the need to comply with port and coastal state laws governing weapons carriage).

347. See Houreld, supra note 14 (stating that in early 2012, Egypt, Oman, and Kenya all changed their rules regarding weapons carriage).

348. BMP4, supra note 166, ๆ 2.4 (defining the "High Risk Area" as "an area bounded by Suez and the Strait of Hormuz to the North, $10 \mathrm{~S}$ and 78E").

349. JUNE 2012 INTERIM GUIDANCE, supra note 203, § 1.6.

350. Maps of the "High Risk Area" suggest the following coastal states: India, Pakistan, Iran, Iraq, Kuwait, Bahrain, Qatar, Saudi Arabia, United Arab Emirates, Oman, Yemen, Egypt, Sudan, Eritrea, Djibouti, Ethiopia, Somalia, Kenya, Tanzania, Madagascar, and Mozambique. BMP4, supra note 166, at $86-87$. 


\section{CONCLUSION}

The fight against maritime piracy is a worthy one. Yet, the international community suffers if states permit private armed guards to participate in that fight without also taking steps to guarantee that those private actors will act lawfully and properly. While the military personnel participating in the anti-piracy patrols are not perfect, they are generally trained, under an officer's command, and subject to disciplinary proceedings or other potential actions should they fail to act lawfully and properly. Currently, however, there are no assurances that the private armed guards that ship owners hire are well trained or prepared to follow orders and abide by applicable laws. Moreover, there is no guarantee that private armed guards will be punished should they fail to act lawfully.

Fighting the international crime of maritime piracy requires international coordination and transparency regarding the rules that will govern the use of private armed guards. To continue with a system whereby each state creates its own rules, or no rules at all, creates the risk of "Blackwater moments." 351 All civilized states should view such a risk as unacceptable and therefore take responsibility for regulating and monitoring the private actors that they are authorizing ship owners to hire for protection against pirate attacks.

351. See supra note 14 and accompanying text. 